\title{
The Elementary Forms of Religious Life: Discursive Monument, Symbolic FEAST $^{1}$
}

Ronjon Paul Datta

TARa Hope Milbrandt

Dedicated to the memory of Ivan Varga 1931-2012.

Professor Emeritus of Sociology, Queen's University at Kingston, Honorary President, Research Committee on the Sociology of Religion, International Sociological Association

Keywords: sacred, solidarity, morality, Durkheim, human sciences, social theory

Mots clés: sacré, la solidarité, la morale, Durkheim, sciences humaines, la théorie sociale

\section{INTRODUCTION}

Sociologists and historians tend to meet in the confirmation that religion is the most primitive of all social phenomena. From it, by successive transformations, have come all the other manifestations of collective activity: law, ethics, art, science, political forms, and so on. Everything is religious in principle (Durkheim [orig. 1897] 1978: 123).

1. Inevitably, when one reads texts from a different era, s/he encounters the spirit and writing conventions of that era. We wish to acknowledge that Durkheim's books and articles were written in an era in which gender neutral language was neither used, nor widely regarded as significant. Today, by contrast, gender inclusive language within the human sciences is a rightly established social fact. To avoid the risks of mistranslation through modernization, we have decided to retain the terminology from all original texts and translations throughout this volume. 
A religion is a unified system of beliefs and practices relative to sacred things, that is to say, things set apart and forbidden — beliefs and practices which unite into a single moral community called a Church, all those who adhere to them (original emphasis; Durkheim 1995 [1912]: 44, i.e., The Elementary Forms of Religious Life/ Les formes élémentaires de la vie religieuse, hereafter abbreviated as EFRL or shortened to The Forms).

$\int$ ine he focus of this special issue for the Canadian Journal of Sociology is Émile Durkheim's book, The Elementary Forms of Religious Life and contemporary engagements with it. In honour of its centenary, we bring together ten original contributions joined by their shared engagement with Durkheim's powerful text. This collection can be read as a living manifestation of the contemporary relevance of The Forms, a testament to its capacity to elicit new questions about the nature of social reality, elucidate the social forces animating forms of collectivization, and stimulate creative directions within contemporary social theory.

In The Forms, his arguably greatest work, Durkheim explicates the elemental social basis of religion to uncover its ultimate foundation in the "real," declaring from the outset that "there are no religions that are false" (EFRL: 2). ${ }^{2}$ Religion for Durkheim emerges from the substratum of the social since what the collectivity values "is the source of all religious experience" (cf. EFRL: 274; Milbrandt and Pearce 2011: 269, $270)$. Broadly defined as a system of obligatory beliefs and practices relative to sacred things, religion is no mere epiphenomena; rather, it is a necessary and constitutive element of all viable collectivities (EFRL: 429), from the White Cockatoo clan of pre-modern Australian totemism to contemporary Canadian society. Today, we extend this to the globe, as witnessed by such things as the collective effervescence of World Cup football, communicated by the collective representation of the "buzz"of vuvuzelas emanating from televisions around the world, transcending and linking societies together in a vibrant cosmopolitanism "from

2. As Fields points out, the French word "élémentaires" can be translated as either "elementary" or as "elemental." "Elemental" serves to remind the reader that "Durkheim is interested in "a fundamental and permanent" aspect of humanity and its "ever-present source," which can be discerned if studies in what he take to be its elemental forms. Whatever those forms are $[\ldots]$ they have an underlying identity that persists despite unceasing change and limitless diversity" (1995: lix-1x). An additional exemplar of this method is found in Durkheim's lectures on socialism (1962) in which he examines all the varieties of socialism to distill what they have in common. Mauss described Durkheim's explication of his approach to socialism "as a model of the application of sociological and historical method to the analysis of the causes of an idea" (1962: 34). 
below" (Datta 2012: 531; Turner 2006a; Inglis 2011; Inglis and Robertson 2008).

This collection was itself conceived in the aftermath of an effervescent conversation, about how Durkheim's last major text warrants new engagement and re-examination, especially in light of contemporary theoretical developments and socio-cultural formations inviting Durkheimian analysis or intervention. In this introduction, we discuss the features of the enduring impact of The Forms and offer a brief overview of the book. We invite the reader to apprehend The Forms as a discursive monument, one that occupies a strikingly nodal place within the discursive networks of the social sciences. As a discursive monument, The Forms has been "left by the past" (Foucault 1972: 7) and yet it stands. Its production is a singular "event" (Foucault 1972: 8 ) affecting the human sciences as a monumental work in many major theoretical traditions both positively and negatively. The Forms can also be taken up as part of a symbolic feast of social analysis, nourishing a range of interpretive approaches. This circumstance, we are pleased to say, is evinced by the range of contributors' work here. Most significantly, they are reminders of the salience of the questions Durkheim posed concerning the very constitution of social life (cf. Milbrandt and Pearce 2011; Ramp 2010; Datta 2008).

The analytical and explanatory power of the concepts in The Forms makes it possible to extend Durkheim's conception of how collective power is symbolised in enduring, existentially meaningful, consecrated, totem-like forms beyond his immediate empirical referent of central Australian tribes. The concept of the sacred can be applied to a wide range of phenomena, from the rather ordinary ritual and meaning of donning one's "Sunday best," to extraordinary global social facts such as the revolutionary collective effervescence witnessed in Eastern Europe in 1989 (Tiryakian 1995). Many recent theoretical developments, notably heterogeneous, build upon The Forms. These include Jeffrey C. Alexander's sociological conception of justice developed in The Civil Sphere (2006) and Julia Kristeva's psychoanalysis of revolution in Revolt, She Said (2002), among many others. The Forms also functions as an on-going foil for Giorgio Agamben's influential genealogy of politics, religion and economics (2009).

Although The Forms has been read for over a century, 2015 marks the twentieth anniversary of the publication of Karen E. Fields' translation of the book into modern English, together with corrections to footnotes, references and maps (Fields 1995: lii). Fields' translation and introduction both consolidated and opened up a new era in Durkheimian studies. Indeed, her stated hope was to facilitate new readings and study of The 
Forms both within and beyond sociology and anthropology (xxiii). Her work has been invaluable to our own. The reliance of English-language Durkheimian studies on her translation, including the bulk of the contributions below, is indicative that Fields' hope has become reality.

There are several features of this project. First, the spirit of the collection is one of creatively appropriating Durkheim's work to develop novel lines of sociological inquiry, even in cases where what is creatively developed arises from critiques of The Forms. This is significant as it highlights the extent to which generations of justified criticisms of Durkheim's work have not led to its abandonment. ${ }^{3}$ This suggests that what is enduring about Durkheim's book is its theoretical visuality (López 2003; Woodiwiss 2005), its method of rendering realities of human life empirically apprehensible within the order of social scientific discourse, despite contradictions and aporias in the text. Second, we draw attention to the disarticulation of the sacred-profane distinction from "religion" proper. For Durkheim, as for the contributors in this issue, sacred and profane powers can be found quite outside the domain of formal religious institutions, from highly charged occasions to the most troubling domains of social life. Third, we note the optimism about social life that Durkheim's sociology offers. In contrast to the rather unquestioned tendency in much contemporary critical social science to view morality with suspicion, the cultivation of strong and affective social bonds can be regarded as a positive basis of collective life, as a "good thing" and condition of existence for human flourishing. Morality can guide humane and democratic judgments; it need not be viewed as a social fact to be a priori denounced as inherently complicit in a dubious status quo. One of the major lessons of Durkheimian sociology, after all, is that healthy manifestations of social life are an ontological foundation (an elementary potentiality) to be differently leveraged to enhance the conditions of human flourishing (cf. Watts Miller 2012; Pearce 2001; Datta 2010).

\section{ConteXtualizing Durkheim's InTervention}

The theoretical and practical reference points for Durkheim's sociological programme are explicitly the French Revolution, the unfulfilled promise of the First Republic and the abnormal form in which French society in particular, and Western European society in general, developed. This inhumane and unjust development was signified by class warfare, wide-

3. Rosati provides an extensive list of the varieties of critical and productive appropriations of The Forms (2008: 252 n. 13). 
spread despair, increased rates of suicide, sclerotic democratic and state forms, and the uneven development of educational institutions (Milbrandt and Pearce 2011; Fournier 2013). These conditions impeded the necessary development of plural bases of a democratic-communicative infrastructure necessary to adequate conscientious considerations of social justice, i.e., a concern with the well-being of society as a whole, which would require the full inclusion of all social groups. In a word, the most advanced, complex societies were "anomic."

The human sciences, Durkheim's included, sought to address the real impacts of the industrial and French revolutions (cf. Foucault 1994: 345). The privileging of state-facilitated industrial and economic growth characteristic of Louis Napoleon's French Second Empire had led to abnormalities in the division of social labour, the unequal allocation of socially necessary resources, and serious social pathologies causing human suffering. The France of Durkheim's day, the Third Republic (1870-1940), while full of promise, was in a precarious state. The German defeat of France in the Franco-Prussian War (1870-1871) challenged nationalist grandiosity. This was accompanied by divisive ideological debates between liberals, socialists, conservatives, and clerics concerning the direction France should take (Milbrandt and Pearce 2011, 240-242). The brutal, murderous crushing of the Paris Commune in 1871 by the state served as a chilling caution to revolutionary idealists (Stedman Jones 2010; Ramp, this volume). Durkheim sought practical, viable and desirable sociologically derived solutions to these serious problems. A central task for a healthy and normal modern state form was to attend to the facilitation and celebration of "moral individualism" in all facets of society for all persons (Durkheim 1973). For Durkheim, broadened democratic politics was a means to the end of empowering people to be able to experience the benefits of collective life, endure tragedies because of social support, and facilitate creativity and flourishing.

In Durkheim's own lifetime, a belief in the potential for a more humane, pluralistic and substantively egalitarian society recalled the creative collective effervescence of the French Revolution (EFRL: 213, 430). Today, we witness a rekindling of transformative democratic and socialist ideals against conditions that can be understood to violate a modern society's "need of justice" (Durkheim 1984 [1893]: 322; Pearce 2001: 71-83). This can be seen through coordinated and effervescent manifestations against authoritative regimes (the "Arab Spring"), challenges to neo-liberal attacks against workers ("Occupy" and "anti-austerity" movements), and movements directed against colonial legacies (e.g., the indigenous peoples' "Idle No More" movement in Canada). Crystallized collective representations expressing ritualistic street mani- 
festations (e.g. "We are the 99\%!") and transnational expressions of solidarity can be read as signs of an increasingly integrated, albeit highly uneven, international society. Energized by intolerance for injustice, such movements are suggestive of a shared conviction in the ideals of a just society that transcends individual nations (Durkheim 1984 [1893]: 322). Such movements seem to us consistent with Durkheim's conception of the (sacred) ideals that modern society arouses within the souls, or consciences, of its members. ${ }^{4}$ Collective movements and political formations organized against exclusionary practices and divisive politics can thus be understood as indicating that the moral needs and ethos of an increasingly differentiated global society have been transgressed, suppressing the development of genuinely organic, cosmopolitan solidarity.

\section{Social Institutions and The Forms}

The discursive reach of The Forms across the human sciences can, in part, be accounted for by the range of social institutions and phenomena that Durkheim sought to describe, analyse and explain. The research programmes of the Durkheimian team centred around the publication of the journal L'Année Sociologique are indicative of the range of social facts under consideration, with the study of religion afforded a privileged place. When the journal was founded in 1896, a section of reviews was reserved for the Sociology of Religion, among General Sociology, Juridic and Moral Sociology, Criminal Sociology (and Moral Statistics in Volume 4), Economic Sociology and Miscellaneous, (dealing with elements of social morphology for instance) (Fournier 2013: 276).

The central focus in The Forms is Durkheim's account of the constitutive components from which the social institution of religion is composed. It is important to note that for Durkheim "religion" is a sociological concept referring to one among several major social institutions in complex societies (e.g., law, morality, the family, work, the state, etc). Durkheim, in 1909, while explicating the central logic of his sociology and making a case for the essential role of the comparative-historical method in sociology, lays out the contours of institutional analysis as follows:

The principal problems of sociology consist in researching the way in

4. The French word "conscience" means both "consciousness" and "conscience"; here we use the French word. Durkheim exploited both of these senses in his use of the word conscience using it to refer both to the conscience individuel (the consciousness and conscience of individual persons) and to the conscience collective (the consciousness and conscience of a society as carried and sustained by collective representations especially). 
which a political, a legal, moral, economic, or religious institution, belief and so on, was established, what causes gave rise to it, and to what useful ends it responds. [...] In effect, to understand an institution, one must know of what it is made. It is a complex whole, comprised of parts; one must know these parts and be able to explain each of them separately as well as the way in which they are combined (Durkheim 1978: 82-3).

Durkheim's methodological reasoning is instructive as concerns his conception of sociology as a science of institutions and how institutions contingently combine to constitute a society because with Australian totemism, the institution of totemism and society are one and the same. Thus, to describe, analyse and explain totemism as the elemental form of religion is at the same to time to describe, analyse and explain the elemental form of institutions. Further, the simplicity of the Australian case makes it possible to describe, analyse and explain the constitution of a society. This works in the case of Australian totemism because the institution is totalising, enframing all facets of human-social existence.

\section{The Forms and Durkheim's Sociological Problematic}

The Forms consolidates work on two concepts central to Durkheim's entire sociological programme: solidarity and collective representations. These concepts are markers of what we take to be Durkheim's fundamental theoretical problematic, namely, the conditions of possibility of social life. Solidarity is a concept designed to explain the kind of force working in and through individual persons, an essentially moral force compelling them from within to act in the interests of others, even when they do not feel so inclined and may prefer to act egoistically (Durkheim 1984 [1893]). Solidarity refers to people's sense of social attachment, their capacity to satisfy moral obligations share concerns and responsibilities in common with others, all of which are necessary to societal integration (Watts Miller 2012: 37ff.)

Durkheim's scientific revolution was to have found epistemological means for opening the continent of a science of morals, including moral feelings/sentiments, without the aprioristic romantic baggage of supposing that people are born "good." Collective representations like totems, language, the calendar, a flag, currents of public opinion, ideals such as freedom and equality, or monetary currency, to name but a handful, are external carriers and markers of solidarity. As such they are "social facts," external to any particular individual or group; they cannot be changed through an individual act of will, and are thus coercive upon individuals' egoistic inclinations. Social facts are regulative of people's actions, obliging members to honor socially instituted ways or face sanc- 
tions, whether these take the form of ridicule, (e.g. if one commits a "fashion crime" [cf. Durkheim 1982: 51]), derision, or formal punishments meted out by the state. They are also typically general or pervasive throughout a society. Collective representations are a repository of frameworks for thought, communication and social action that have become crystallized, facilitating coordinated life with others, and prescribing "ways of acting, thinking and feeling" (1982: 52). While we highlight the significance of collective representations, it is important to emphasize that Durkheim rejected a purely cognitivist sociology. In The Forms in particular, he illustrates the importance of enacted social practice in the creation, renewal, and transformation of collective representations. This is highlighted by Anne Warfield Rawls (2001; 2012) whose work draws attention to the ethnomethodological reading of what Garfinkel called “Durkheim's neglected legacy” (Garfinkel 2002: 94).

\section{Summary of The Elementary Forms of Religious Life}

While there is no substitute for reading Durkheim's text itself, preferably in English and French, here we offer a predominantly paraphrased summary of lines of reasoning and central concepts in The Forms, about what we have found incisive in the book. ${ }^{5}$ Of course, an overview of this sort reflects our own editorial choices and admittedly may be seen as unnecessarily "scholastic." Our hope though, is to provide a guide for continuing to engage with the contributions in this volume and with The Forms, portraying what we take to be a discursive survey of Durkheim's ambitious project as a whole.

The original subtitle of the book is "Totemism in Australia" indicating the primary empirical referent for the development of Durkheim's position (Fournier 2013: 603). The book is organized by an introduction, attention to seminal questions, two major sections, the first dealing with beliefs (Book II), the second with rituals (Book III), and a conclusion distilling key points. The primary aim is to analyse elemental component parts (5) in the simplest example of religion known, and explain how the parts combine to produce an enduring, institutionalised form of moral community. In turn, this constitutes the conditions of possibility of society itself and the resultant collective human capacity for reasoned moral reflection, judgment and understanding (Stedman Jones 2001). The data were especially drawn, if imaginatively (Watts Miller 2012: 151ff.),

5. Joseph Ward Swain's 1915 translation of The Forms is freely and publicly available through Project Gutenberg at: http://www.gutenberg.org/ files/41360/41360-h/41360-h.htm. Issues with Swain's translation are discussed in Fields (1995). 
from the anthropological writings of Walter Baldwin Spencer and Francis James Gillen's books Native Tribes of Central Australia (orig. 1899) and The Northern Tribes of Central Australia (orig. 1904). Relying on, J. S. Mills' argument that explaining a single case in methodologically rigorous form is sufficient to establish a theory (418, cf. 92), Durkheim sought to conduct a sociological analysis in which all religions, primitive and modern are discussed "on equal terms" (Fournier 2013: 605; cf. Rosati 2008), thus distinguishing his work from that of Lucien Lévy-Bruhl (cf. Tiryakian 2012). Finding the simplest case was important given the historical development of complex societies with their wide variations of religious beliefs, practices and syncretic combinations (5). Durkheim resolves this problem with his usual method of seeking to identify elements common in all instances of a belief system, restricting himself to developing a definition amenable to a positive science of religion, i.e., one that can be based on (but not reducible to) observation and dependent on analysis, breaking the phenomenon down into its most basic components.

Durkheim announces the result of his work in his introduction, arguing for the social origin of religion, encapsulating collective life in shared symbols that in turn guide ritual practices that sustain and renew the group (9). Stressing his ambition early on, he advances an argument that the basic conceptual framework of human life, involving conceptions of time, space, genus, force, personality and their active, communal combination in the work of reason, is fundamentally social in origin (10-18).

True to his "scientific rationalism" (Durkheim 1982: 33; Stedman Jones 2001; Gane 1988), Durkheim begins by providing a definition of religion. Because researchers inevitably bring preconceptions to their studies, it is preferable to develop and reflect systematically on how various preconceptions are likely to shape the development of a scientific research programme, rather than risk relying on intuitions or unexamined preconceptions. He dispenses with influential theories of religion including those stressing that religions arise as a means to deal with what people find mysterious since the beliefs in sacred beings tend to facilitate the routine workings of social life and are certainly not reserved for things deemed inexplicable (26). Neither can religion be understood as being based on a belief in divinity since there are religions that do not depend on a belief in a god; Buddhism is a prime example. Durkheim, largely following his earlier piece from 1899, "Concerning the definition of religious phenomena" (1994a), advances a "positive" definition of religion stressing that belief systems and obligatory ritual actions are fundamental to religion (34). However, in contrast to his earlier definition, he now emphasizes the sacred and its distinctiveness from the profane. 
Religious beliefs and rites pertain to two different classifications of real and ideal things designated by the Latin-based categories of "the profane and the sacred" (34). Because the sacred depends on the social practices of sanctified persons like priests, any part of human reality can become sacred, depending on whether it is treated in special, ritualized ways (35). This also implies that sacrality cannot be derived from how humans experience nature. Rather, it derives from what fundamentally pertains to collective life and is radically differentiated from profane existence with its individualistic orientations and interests i.e., "egoism", especially those associated with utilitarian and economic matters. This difference between the sacred and profane is substantial, dealing in markedly different realities affecting human existence in radically heterogeneous ways (36). Profane life is deemed subordinate to the sacred realm and dependent on it. Religious beliefs and the rites guided by them specify how communication and movement between the sacred and profane spheres is to be conducted. Male initiation rites are a prime example of this because they radically transform a boy for entry into adult religious life and full communal membership. Initiation amounts to a series of practices of cleansing the boy of his profanity and subjugating it. In short, the sacred and profane refer to two fundamentally different, opposed, but intimately connected worlds. Religions are constituted when a system for coordinating and ordering sacred things has been established (38).

In contrast, magic is derivative of, and distinct from religion, even while containing beliefs and rites, because magic is rather about the use of technical knowledge to achieve the utilitarian end of a person seeking the services of a magician. Magic is thus more like doing business than like religion. Unlike religion it has no need of bonds of mutual obligation or an institutionalized collective like a church to sustain them (42). Durkheim concludes this section with his definition of religion (quoted in full at the start of our Introduction). The remainder of the book mounts a comprehensive defence and explication of the theorem.

Using his standard rhetorical device of criticising predominant theories of the day to make his own seem more plausible, Durkheim challenges animism and naturism. The animistic theory influentially advocated by Edward Tylor contends that religious beliefs stem from the difference between wakeful and dream states in people. In dreaming, people experience their soul and the souls of the dead. For Tylor, death liberates the soul from the body to become a spirit that still affects the lives of the living, serving as the basis for the development of religious ideas. Naturism, exemplified within Max Muller's work, holds that religion emerges from imaginative solutions for explaining natural phenomena like light- 
ning. People come to believe that such forces are manifestations of a personified spiritual entity and thus are born the gods. Naturism, however, does not have a way to explain the radical difference between sacred and profane things, especially the awe and respect that are part and parcel of religious feelings, ones that frequently are attached to natural things people routinely encounter being treated as sacred in totemic religions. Naturism thus cannot explain the emergence of something super-natural (83-84). The difference between the sacred and the profane lacked an adequate explanation.

Durkheim postulates that ethnographic descriptions of totemism provide evidence of the earliest form of religion. Totemic religions, as found in Australia and North America, reflect the social basis of the elementary distinction between the sacred and profane not least since the totem plant or animal also constitutes the basis of societal organization, the latter implying the formation of a moral community (93). Durkheim focuses on the Australian case of the Arunta in particular because North American cases involve more advanced and complex forms of social organisation, indicating that they have gone some distance from their origins and hence are no longer elementary (93-94).

Book II addresses the elemental beliefs of Australian totemism as an emergent system, grounding them in an analysis of clans as the basic grouping of collective life. Clans bind individuals in kinship, that bond being represented by the name of a totem, whether a plant or animal species (103). Clans exist within a tribe and in inter-tribal relations. The totem name is what distinguishes a clan as a group from other groups, individuals, things and places that do not belong to the clan. The emblem is thus a marker of membership, symbolising what is exclusive to the group (181). Australian tribes consist of two phratries each consisting of several clans. Members of a phratry are obliged to practice exogamy (marrying outside of the group). Members of the clan are also bound by a system of obligations that concern helping each other, mourning and joining forces to fight enemies.

This system for organizing social life is united by the dominance of the totem as emblem, providing the means for designating to whom obligations and rules apply. Totemism is thus both a system of knowledge, facilitating classification of what belongs where, and a system of obligations pertaining to moral life. However, the totem is more than a name; it is rather a powerful symbol of the collective (111) and is above all "written" (Gane 1983; cf. Masuzawa 1988), whether traced on the ground at a burial site (113) people's dwellings, or things used in daily life (114). It is on the body itself that the totemic symbol is frequently written as found with tattooing (116), or when painted on a newly initiated person upon 
first entry into a sanctuary (117). To take a contemporary example, the rainbow flag, ubiquitous during LGBTQ pride marches and designated "pride" times in cities around the world, offers a vivid example of the group emblem as powerful "rallying sign" that symbolizes, affirms, and reconstitutes the group (local and transnational) to and for itself. Participants adorn their clothing with this emblem, paint it on their faces and bodies, and wave it in the air during ritualistic street parades.

A recurring example of sacred ritual objects in The Forms are churingas. These objects have the totemic mark of the group and great care is taken to look after them (118). They are the holiest of objects, set apart and forbidden to women and the uninitiated (119). They are kept in a hidden sacred place, separated from profane daily life, constituting that place as the holiest of holy places. Because holy places are protected by collectively imposed interdictions, they can also be used as places of refuge (120).

By analysing the uses of totemic markings, Durkheim argues for a homology between the totemic emblem and religious life because totemic emblems have a predominantly ritual use in collective ceremonies. Thus while it is a collective label, the totem is also a profoundly religious thing (118). Durkheim here follows a methodological principle of using the description of setting apart and forbidding by the community to argue that totemism is indeed an elementary religion precisely because it has a system for sacral differentiation. The sacred character of the totem mark (124) emerges from the power of the clan being signified in material form - it is the totemic symbol itself that is sacred, not the material objects or bodies on which it is written (133).

Totemic emblems as collective representations of the group, together with the system of social organisation, result in cosmologies constituting the first form of a genus necessary to operations of logic (148). The logical hierarchy of the terms genus and species in which a species belongs to a genus, stems from totemic cosmologies in which the collective totem takes primacy over individual totems, the former constituted by rituals pertaining to the group and the latter given to individuals at birth to designate their specific place in the group (179).

Durkheim's explication of totemism as inextricably linked to social organisation is also elaborated in terms of a totem belonging to an individual, and totems dividing the tribe into two sexes: male and female. An individual totem is tied to the name of an individual and is associated with an object that is the sacred property of that individual. This name is sacred and is not used in everyday life (159). The individual totem is generally worn or tattooed. In the case of individual animal totems functioning as patrons to persons, the characteristics, virtues and vices 
imputed to the animal are deemed to be shared with the human in a kind of similitude (160). Examples of the relationship between humans and animals in contemporary mythological representations include a "familiar" attached to a witch (e.g. a black cat or a goat) or Voldemort's snake Nagini in the Harry Potter series. While the individual animal totem is a patron, the human has power over the animal (161). The cult of the individual totem emphasizes the on-going ties between individuals and the materials of daily life (162). Whereas an individual in a clan is seen as offspring of the clan's totem, in the case of the individual totem, that relation is more like one of friendship (162). The totem of the clan provides a collectively protected identity for all members (163) and is combined with the individual totem to constitute something akin to a surname and a sacred first name designating the specific place and powers of an individual within the clan.

Sexual totems refer to a tribal totemic system differentiating between the sexes, inclusive of all men and women in all clans of the tribe. The sexual totems constitute two rivalrous groups (167) with ties to respective mystical, protector, sacred animals from which all are deemed to have descended (167). Like the clan, sexual totems are also collective (167). The tribe itself is believed to be the spawn of a mythical pair of ancestors. The sacredness of each sexual totem must be respected by both sexes and they live the bulk of their collective lives segregated from each other (168). There is thus a continuum of totems with individual totems on one end, then sexual totems in the middle, and tribal totems at the other.

With a cosmology derived from the totemic system, all people, things, places, etc., that are part of clan life are seen to depend on, and be suffused with, a totemic principle because it is an impersonal, immanent life-force. The basis of religious belief systems is thus exemplified in ideas of such impersonal, pervasive forces like those evinced by the Melanesian notion of mana (202). These forces do more than take nature as their referent; they also refer to people's sense of obligatory conduct, impacting morals - aboriginals faithfully and rigorously practice rites because their exemplary ancestors did so (192). In short, the totemic principle unites the totality and workings of the cosmos, encompassing both nature and social life.

Durkheim concludes Book II with three famous theoretical developments. The first is the rough equation of "totem $=$ god $=$ society" (cf. Lacroix 1979; Pickering 1984: 231-235; Fields 1995: xxxv-xxxviii), the second his concept of "collective effervescence," and the third a theory of the soul, of spirits and "high gods." Concerning the first theoretical development, "Durkheim's theory is extremely forceful: he considers 
gods as a symbolic form through which men [sic] can worship collective life, though he never makes a pure and simple identification of God and society" (Rosati 2008: 242). For Durkheim totems are highly emotionally charged symbolic expressions of the belief in the totem principle, a belief in something like divine omnipotence. As he states, the totem "is the outward and visible form of what I have called the totemic principle or god; from another, it is also the symbol of a particular society called the clan. It is the flag of the clan" (208). Durkheim's reasoning also suggests, however, that religion with its gods is really a misrecognition of society and its power because the totemic principle is imaginatively transformed by synthesizing a belief in the totemic principle with the natural substrate of a specific animal or plant species (208); something else emerges from this combination irreducible to the properties of its constituent elements. Hence, the "equation" of god and society is not simple. The misrecognition is likely both constitutive of religion and inescapable given how, in Durkheim's view, humans synthesize consciousness of matter in sensations, sensations themselves immediately being synthesized with collective representations to form individuals' perceptions, the world that spontaneously "makes sense" to people (cf. Stedman Jones 2001; Lacroix 1979; Strawbridge 1982).

How people experience religious powers is homologous with their experience of the power of society. The source of all power, including that of authoritative individuals, is society $(210,215$; Pearce 2001: 33-38; Lacroix 1979), and to experience the sacred is to frequently be empowered by communion with it. Divine power and authority is not simply an external coercive force but one that can empower the believer (211; cf. 419). One's god has the power to fundamentally change oneself as one might find with conversion experiences. Indeed, collective power can be radically transformative, as found for instance during the French Revolution in which otherwise ordinary persons acted heroically or even murderously (213).

A specific kind of event generates an experience originative of this system of beliefs about power, namely "collective effervescence." Echoing Mauss' (1979) study of the oscillations of social life among the peoples of the Arctic, Durkheim notes that social life in Australian tribes alternates between two phases: a less social, economically-oriented, rather dull, and routine period pertinent to subsistence, and a second period like corroboree, an electrifying, emotionally intense, physically engaging gathering including all members, even the uninitiated (217). Being in proximity with others itself energises participants. Encouraged by seeing and feeling others behaving outlandishly, transgressing routine expectations about appropriate conduct, and breaking out spontaneously 
in music and dance (218), it becomes a moment of shared extreme emotion and movement. To use a Nietzschean turn of phrase this is an experience "beyond good and evil" when the laws and morals pertaining to routine social life are suspended, much as they are for the gods as depicted in Greek mythology - it is a state in which the "exception" is the "rule" (Datta 2010). People's experience of the radically different power of the collective, generative of a belief in the power of the sacred, is produced on such occasions.

This social force is ecstatic (228; from the Greek, "ekstasis") in which people "stand" (stasis) "out of" (ek-) their usual placement in the order of tribe, phratry, clan and routine activities associated with daily life. The spatial organisation of the sacred (e.g., temples and sanctuaries) thus finds its origin in temporality, in the collectively effervescent event (Datta 2010: 177). Collective effervescence generates a unique force constitutive of moral life, empowering people with the capacity to transcend egoistic, individualistic orientations, concerns and practices characteristic of profane life. It does so by giving people an experience of acting very differently than they usually do, with the group being the referent of that action.

The powerful, overwhelming feelings experienced in collective effervescence are transferred to the totem animal or plant by a sort of contagion to endure as a revered symbol to which people are passionately attached (232). It is in this respect that the effervescent assembly is creative (Pickering 1984, 386), generating a new contingent assemblage of "words and things" (Datta 2008: 292). This also how "creative collective effervescence" as found during the French Revolution can be revolutionary without being destructive (Stedman Jones 2001: 213). The totem symbol functions as a mnemonic device of the ecstatic occasion (222), becoming a highly crystallised collective representation of the power of the social (a social fact), and an elemental condition of possibility of social life (225). The totem symbol becomes a generalized existential referent for epistemic, ontologic, affective, normative and aesthetic judgments. Things deemed sacred become so by the application of the collective representation of the totem emblem to them, providing a conduit for an on-going communication of the idea and experience of social/ sacred energy onto things so marked $(231 ; \mathrm{cf}$. 424), superimposing them on nature (230; cf. 424).

The final section dealing with the elementary beliefs of religious life explicates how the notion of soul provides the basis from which ideas about spirits and finally tribal gods emerge. Durkheim's theory of the soul attends to the social constitution of personhood and subject formation. Individuals are constituted through a synthesis of their body and a 
soul that individualizes the life of the totem principle for a person, ensuring the group's perpetuity in that person (263-267). The soul, while closely bound to the body, nevertheless has an independence from it and lives after death. Funeral rites typically involve means to encourage the soul to leave the body (246) and go to its own specific world, something akin to heaven (247-248). Durkheim argues that the soul is part of the totem principle embodied in individuals (251). Because each empirical, physical individual has its own consciousness, each soul is different (251). Durkheim links the soul to its collective origin by noting that it contains one's highest self and the basis of one's moral consciousness (251-2). For Durkheim then, the conventional, typically liberal, theoretical opposition between the individual and society is misleading; the individual soul depends on the collective soul and the life combining the collective continues in the lives of its individual members $(252,269)$.

The totemic being is believed to be the soul of an ancestor that continues to be bound to individuals through churingas (258). The origin of the tribe is believed to have stemmed from various ancestors (259). An overlapping socio-logic of totemic principle, ancestors, and souls allows Durkheim to point to the sacredness of the soul, containing a divine spark, whereas the body is associated with the profane (265), not least since the body individualizes consciousness via the senses (275) forming a physical substratum to the social constitution of subjectivity and personhood (274). The social source of the soul gives it a reality outside the minds of subjects (265) because it comes to the individual from the external social world, originating from the shared idea of a totemic principle like mana (252). This lends moral force to the soul, constituting people's capacities as moral agents (266). The double constitution of human subjects emerges from the articulated combination of the dominance of the soul (266) with its collective origin associated with the totem principle, residing in and guiding the body-profane (273). One might be tempted to call this something like the "social DNA" of the population (e.g., "A love of hockey is in our collective DNA.") The soul is the agency making it possible for people to transcend merely egoistic and/ or animalistic inclinations. Souls are believed to have the power to make other souls, providing for the enduring existence of the life of the group that transcends the lives of any of its individual members (272).

While the collective soul is impersonal and a property possessed by all members of the group, an individual soul is personal reflecting a synthesis of the distinct empirical embodied locations of each individual and the unique perspective arising from this. Individuals thus are able to appropriate the sacred in their own way making it meaningful to them in their specific circumstances (273; cf. Durkheim 1982: 47 n6). Hence 
Durkheim anticipates Foucault's theorem that "the soul is the prison of the body" (Foucault 1979: 30); for Durkheim, the soul personalises the power of the social enabling people to regulate their desires (275; Fields 1995: xxix).

Having linked the substance of the soul to the enduring life of the group, Durkheim develops his analysis to account for the ideas of spirits and gods. While the soul is intricately linked to the body, spirits are not so tied to the body and are able to move about (276). A ghost is not a spirit because lacking obligations to the group, whereas spirits have power, authority and are responsible for doing things in the world (277-281). Spirits are typically beneficent but a belief in malevolent spirits (286) emerged to explain human miseries (284). Spirits mark the further "individuation of religious forces" (286). Totemism as an elemental system of religious beliefs thus provides means for understanding how individual souls that personalize the totemic principle become privileged ancestor spirits that subjugate others to become high gods (299).

The institution of the tribe and its subdivisions (286) is central to the development of a notion of gods believed to be highly valorized totemic beings, specifically, mythologized ancestors (293-294). The rites of the tribe, especially those of initiation, pertain to all subdivisions and are practiced in the same way. Initiation is a tribal ritual in which the cult of a high god like Altjira, is celebrated (291). Tribal high gods represent the tribe to other neighbouring tribes and hence exist in an international context (292).

The notion of a high god seems to have emerged from the notion of "civilizing heroes," special ancestors deemed to have been key to the development of the tribe (294). A civilizing hero is so because he is believed to have inaugurated the basis of central social practices and institutions like religion (294). High gods, closely related to civilizing heroes, are fundamentally totemic in nature. Legends indicate that high gods emerge from hostilities between totems. Durkheim argues that the high god of the tribe is the representation of the spirit of an ancestor, an ancestor that defeated others (299). The ascendance of one high god (totemic being) is deemed to morally justify the exclusion of the vanquished and their subjugation to the dominance of the victor (296). High gods are especially celebrated for their creative power of being able to reconstitute boys as men during initiation rites. The high god's governance of initiation demonstrates their dominance over all persons in the tribe and hence too, pointing to something "universal" for all tribe members. In short, the high god combines all of the totems to represent a supreme totality (298). An international mythology emerges as a consequence of the international (inter-tribal) recognition of gods and exchanges between 
tribes (298). With his analysis of elementary beliefs, Durkheim aims to link the empirical body, individual and collective representations, the social constitution of the person, the combination of subgroups (e.g., clans) and the tribal totality. The belief in the totemic principle, itself emergent from the ecstatic event of collective effervescence, subtends all but the body (299). The superhuman powers attributed to high gods reflect the personification of the undifferentiated forces stemming from the shared experience of collective effervescence. As a shared collective representation, the high god captures the experience of the whole facilitating the means by which the tribe becomes aware of itself as a totality (299). These elementary beliefs however, also depend on rites and are affected by them.

Book III, "The Principal Modes of Ritual Conduct" attends to elementary rites, this being necessary to completing the theoretical model of the "cult" that combines beliefs and practices. Beliefs, mythologies, cosmologies and doctrines are means for guiding conduct, designed to produce and reproduce experiences of this power greater than the individual, especially in ritual form. Through the cult, groups and their members reaffirm their commitment to the cult hence also reaffirming the basis of solidarity and mutual obligation shared by members. Throughout the five chapters that comprise Book III, Durkheim emphasizes the efficacy of the cult, especially how it contributes to the re-creation of "a moral being on which we depend, as it depends on us" (352). For him, the name for this being is "society."

Every cult consists of a complex and intertwined combination of negative and positive rites. No single rite can be fully understood on its own. Durkheim begins with the negative rites, consisting of prohibited ways of acting aimed at the maintenance of respect for sacred objects. Taking the form of interdictions (taboos), the system of negative rites works to prevent unsanctioned mixing and forms of contact between sacred and profane. Violation (sacrilege) is believed to bring spontaneous physical disorder (e.g. sickness, revulsion, death) to the offender. Additionally, the guilty one (a sinner) is denounced and punished by public blame or disapproval, even if minimally. Stressing that religious prohibitions are categorical imperatives grounded in collective respect, Durkheim re-emphasizes the distinction between religion and magic, pointing to the latter's essentially utilitarian elements.

Spatial and temporal prohibitions govern and define the system of the negative cult. First, religious and profane life cannot spatially coexist, hence the institution of "temples and sanctuaries" (312). Second, profane and religious forms of life cannot temporally coexist, hence the institution of "holy days" (313). Consequently, there is also a separation 
of activities according to days defined as religious/holy and secular. For example, inasmuch as work is defined as a profane activity, its cessation is required during days set apart as holy. Spatial and temporal separations are most pronounced in simple societies where group life is clearly delineated by periods of concentration and dispersion.

It is important to stress that the system of religious prohibitions is a means to an end, a necessary but insufficient condition for the "positive cult." The cumulative and transformative effects of negative rites are well illustrated in the Australian example of the novice undergoing tribal initiation who is required to bear significant abstinences. It is in relation to this that Durkheim discusses the important role that ascetic suffering plays in all forms of religious life. Far from being exceptional, asceticism is an "essential element" of religious life (316).

First noted by Konrad Theodor Preuss (1904), physical pain is in itself regarded as generative, sanctifying, and even virtuous because it signifies a person's willingness to break ties with the profane world on behalf of the valued collectivity. Durkheim is thus able to draw connections between excruciatingly painful ritual torments undergone by the neophyte during an initiation ceremony hundreds of years before him, and religious ascetic practices more familiar to his (typically Roman Catholic) reader; both dramatize the relationship between renunciation and transcendence, from being ruled by the profane concerns of embodied self and world, to a type of emancipation and "mastery over things" without which society could not exist (320). The reader may at times cringe from examples Durkheim provides of such things as ritual amputations, tooth extraction, or ceremonies that require the novice to lie immobile on a bed of leaves and smoking hot coals (318). The principle at stake is that to serve the gods, the individual must forget him or herself. The most important principle Durkheim is bringing into view here is that if it is to lift us "above ourselves," society requires continuous sacrifices on the part of its members.

Asceticism and painful suffering are intimately connected with the institution of sacrifice. As Durkheim continuously reminds the reader, "religious interests are only social and moral interests in symbolic form" (321). A condition of existence of social life is that members be willing (and ideally, enthusiastic) to place something above their individual (especially bodily) interests, proclivities and concerns. Accordingly, it is important to be mindful of the important relationship between respect and the sacred in Durkheim's account of religious life (cf. 269). Alluding to the emotional energies intrinsic to the rhythms of collective life and shared respect for the sacred, Durkheim writes, "Religious forces are in fact only transfigured collective forces, that is, moral forces; they are 
made of ideas and feelings which the spectacle of society awakens in us, not of sensations that come to us from the physical world" (327).

Sacral contagion is part of what necessitates the cautious separation of sacred and profane worlds. It is important to recall that sacred forces are collective forces communicated, not part of nature proper. Sacredness necessarily carries within it "a certain transience" (322), rendering the slightest contact with the sacred object dangerous. The mobility and radiant power of the sacred thereby creates dangers, demanding that "extreme rigor" be used in the application of prohibitions dividing sacred and profane. A simple illustration of this principle is the importance of ritual washing (e.g., of instruments) preceding a religious ceremony.

The negative cult bridges profane and religious life but to get to the sacred, one must first create distance from the profane. The "positive cult" is the system of rites that organizes and regulates religious conduct. Imaginatively drawing on Spencer and Gillen's works, Durkheim concentrates on the complexities and efficacy of the tribal Intichiuma ceremony of the Arunta. Celebrated by all of the Arunta clans, for Durkheim this ceremony exhibits all of the essential features of the positive cult. In particular, it contains the fundamental elements of sacrifice, that Durkheim identifies as a foundational institution within "the positive cult in the higher religions" (340).

Taking place during the fertile season of nature, the Intichiuma consists of a two-phase celebration. In the first, a series of rites are performed to establish the the health and welfare of the totem species. The second phase involves a heightening of prohibitions to reinforce the totem's sacred power. A final ceremony involves a collective, ritualized preparation and consumption of the totem species.

In his interpretation of the efficacy of Intichiuma, Durkheim builds on, but transforms William Robertson Smith's prior writings on sacrifice. As the ritual meal involves communing with the sacred principle that inhabits the plant or body of the killed totemic animal, god and worshipper become united in the same act. At stake is the renewal of the totemic principle itself so that the tribe may remain itself (342). With his account of sacrificial communion (and contra Smith), Durkheim emphasizes that without the faithful the gods would not exist. The faithful periodically renew and regenerate god, group, and selves simultaneously through ritual offering and communion. The circle of the sacrificial offering generates a microcosm of society. Through acts of communion and offering, "[a person] gives to sacred beings a little of what he receives from them and he receives from them, all that he gives them" (345).

Durkheim's analysis of the positive cult demonstrates how ritual life and social life are one and the same. And above all, it dramatizes 
the importance of collective renewal through collective assembly. Such congregating plays an essential role in developing and revitalizing the self-awareness of the collectivity as such. Although most of the time the demands of life are such that people are more or less dispersed, periodic assembly is a necessary condition for the perpetuity of a group. This is as true for the Australian tribes that occupy the bulk of Durkheim's focus in The Forms as it is for any contemporary group or society. As he states, "Let the idea of society be extinguished in individual minds, let the beliefs, traditions, and aspirations of the collectivity be felt and shared by individuals no longer, and the society will die" (351).

Having established the general importance of the positive cult, especially through the example of sacrifice, Durkheim next examines mimetic (imitative), representative (commemorative), and piacular rites. Mimetic rites draw on two general principles: "contagion" and "like producing like" (360). Consisting of sounds and movements, they both express and recreate the kinship between clan member and totemic species. Challenging Tylor and Frazer's rather abstract explanation, Durkheim argues that as members assemble for the rites, they believe themselves to $b e$ the species whose name they bear. Through assembly, and with the totem emblem as "rallying sign" (362) that gets marked on bodies and emulated through sound and gesture, members affirm their feeling of belonging to a moral community; they "take cognizance of the kinship that unites them" (362). The rite simultaneously expresses and recreates this kinship.

Throughout his writings, and pronounced in The Forms, Durkheim rejects psychologistic or utilitarian explanations of human action to advance a materially anchored form of sociological reasoning. For example, Durkheim draws attention to the efficacy of ritual practices that affect the consciousness of the member. Feeling euphoric from the ceremony, the faithful morally reconstitute themselves. For the practicing member, the efficacy of the system of rites seems inseparable from each single part of the ceremony. It is in relation to this that Durkheim locates the origin of faith, for while the believer does not understand the "specific power prescribed by dogma to each rite taken separately" they nevertheless feel as if "it would be impossible to emancipate themselves from those without falling into moral disarray" (364). What is at stake is not the "truth" or usefulness of the individual proposition or part, but rather the "invisible influence" over consciousness that participation in the whole event creates. Pertinently, it would be impossible to "disprove" the effectiveness of the rite through a scientific experiment, over and against what Durkheim calls this "favorable prejudice" (365). Faith is no simple cognitive 
matter; it is felt within the very soul of the believer. Denial, then, would constitute a moral and existential upheaval for the believer.

Further, drawing on Hubert and Mauss's general theory of magic (2001 [orig. 1902]), Durkheim uncovers its socio-religious origins. People's faith in magic, although seemingly detached from collective life in the figure of the lone magician, itself derives from some previous collective effervescence. Durkheim next expounds on a more general theory of knowledge, drawing critical connections between religious and scientific histories and origins. The "origin of the precept on which mimetic rites rest," he argues, can be used to explain the origin of the principle of causality (366). He discusses the twofold character of the idea of religious "force": it is experienced inwardly, yet moral forces are impersonal and external to individuals. In the case of moral forces, the faithful feel the force internally. Furthermore, they are never fixed in any one individual, and they spread contagiously. Physical forces have similar properties; we perceive their effects when they resist us, "but not the force itself" (369). The human experience of being social provides access to understanding how causality works by moving things within the context of relations with other things. Although it includes the idea of force, the scientific principle of causality includes a reflected judgment concerning the effects of an antecedent cause. Durkheim is hereby challenging both pure empiricism and the aprioristic idea that the intellect is the ultimate creator of the principle of causality. Collective life is the template through which we give meaning to our experiences, providing the means by which we can reason and reflect on them (372).

In his discussion of representative (i.e. commemorative) rites, Durkheim emphasizes how the group regenerates a historical sense of itself, integrating members in time, especially by rendering its "mythical past present" (379). A mythology, Durkheim explains, consists of a moral system, a cosmology, and a history. In a most general sense, commemorative ceremonies revitalize both conscience and (group) consciousness. They also render visible the recreational and the aesthetic dimensions of religious life. He focuses especially on the Intichiuma rites amongst the Warramunga to locate the origin of games and major forms of art within religion. Although Durkheim does not hesitate to remind his reader that religious rites belong to "the serious side of life" (386), recreation is no mere add-on as it constitutes an integral component of the moral remaking accompanying the positive cult.

Religious ceremony is essentially connected to festival, which once again brings into view the primacy of collective assembly within ritual practices. In his discussion of festival, Durkheim highlights the emotional resonances of collective life. Joy and exuberance are not trivial but are 
important elements of group revitalization. A memorable example Durkheim cites is that of the Laughing Boy totem of the Warramunga (383). Throughout his general discussion of commemorative rites, Durkheim re-emphasizes the non-utilitarian dimensions of religious life, highlighting its emotionally powerful, deeply social, creatively effervescent, and morally revitalizing dimensions for the believer. The positive rites engender consciousness of the group, and in so doing reaffirm the moral unity necessary for group survival.

Durkheim's discussion of ritual conduct concludes with a consideration of what he terms "piacular rites." Although both mimetic and commemorative rites belong to the serious sides of collective life, they are nevertheless happily and confidently enacted (392). In contrast, piacular rites are used under trying conditions of loss or fear and are sad and mournful. He emphasizes that mourning is a collectively sanctioned relationship to calamity, a collective obligation like any other, and thus not a "natural" or pre-social response. Why, Durkheim wonders, does the deceased member demand mourning, which may take the form of harsh abstinences or cruel sacrifices?

Like all positive rites, mourning practices bring about a state of effervescence amongst practitioners. To commune in sadness, after all, is still to commune. The crucial sociological point concerning mourning rites is that they constitute forms of moral communion, reaffirming the group that has just suffered a loss. The idea of the soul as outliving the body is found here, inasmuch as the soul stands for a part of the social group being revitalized following a loss or calamity. Poignantly, Durkheim explains that "[p]eople cry together because they continue to be precious to one another and because, regardless of the blow that has fallen upon it, the collectivity has not been breached" (405). Death, illness, insufficient harvests, drought, famine, etc., are different examples of events causing collective distress, worry, or fear, and whose occurrence threatens the collectivity. The collective nature of mourning rites thus "raise(s) the vital tone" (411) and in this way, such rites work to neutralize the same dangers that brought them into being. The group becomes conscious of its power to withstand calamities, precisely by bringing group members together. New memorializing collective representations can subsequently form to mark the loss for the group.

In the final section of Book III, Durkheim develops the idea of the ambiguity of the sacred, crediting Robertson Smith for differentiating between two modalities of sacred: those that are benevolent and pure, inspiring respect and gratitude, and those that contain "horror", i.e. evil and impure powers that bring "disorder, death and sickness" (412). The sacred, in other words, is not simply the good and the holy because it also 
consists of evil and pollution; for Durkheim both symbolize different aspects of collective reality. In addition to the need for both pure and impure sacred to be kept strictly separate from the profane, contact between the two types of sacred is considered a terrible profanation. According to Durkheim, Smith insufficiently accounted for the distinction between pure and impure sacred, thus he devotes the final pages of the chapter to its explanation. Whereas the "pure" sacred belongs to the positive cult, the contaminating powers of "evil", i.e. "impure sacred", Durkheim reasons, must emerge from piacular rites; they are a potent expression and symbolic manifestation of the collective anxieties and emotions that gave rise to such rites, working to neutralize them, for example, through proper burial of the deceased member. Although he leaves the distinction somewhat under-developed in The Forms, the relationship between the "pure" and "impure" sacred, and the theoretical utility of such a distinction, was more fully developed in the work of Durkheim's celebrated student, Robert Hertz (1960), as well as in the writings of Hubert and Mauss.

Durkheim reiterates the central argument and method of the text in his conclusion. The author is confident in having made his case, namely that the most fundamental ideas, essential relationships, and major forms of ritual conduct, are found in the single case of pre-modern Australian totemism (418). Rebutting the scholar who imagines $s /$ he has found the essence of religion in representations, i.e. beliefs, Durkheim reminds his reader of the importance of practices in his account of religious life (420). As emphasized throughout Book III in particular, it is only through the cult that religious beliefs have efficacy. This is another way of saying that a society can only exist if members assemble and act cooperatively. This leads Durkheim to conclude that social reality lies at the core of religion (421). At this point, he returns to the religious origins of the fundamental categories of thought.

Durkheim concludes by solidifying his case that religion stems entirely from social reality and that there are no false religions. He draws attention to the social origin of ideals and images of a "perfect" society. Along similar lines, he explains that immoral conduct expresses the "realistic" dimension of religion: devils, gods and angels are equally aspects of the "real" society, albeit enlarged and transformed (423). Religion thus reflects, and is a representation of, all aspects of social reality, even its most repugnant ones (423). Accounting for the formation of the ideal (424-425), Durkheim acknowledges that a society undergoing change may be divided by conflicting ideals, a conception central to his understanding of transformations taking shape in modern societies. Ideals are fully of the world, because they are formed and communicated to people 
in social life (425). True to his social ontology, Durkheim stresses that that collective consciousness depends upon a prior "sui generis synthesis of individual consciousnesses", the product of which is "a whole world of feelings, ideas, and images that follow their own laws once...born" (426).

Referring to modern society, Durkheim's discusses increasing differentiation and the cult of the individual. Though individualized religion may on the surface appear to complicate his overall account of religion, religious forces being engaged in such cases remain instanciations of social forces (427). Personal piety may keep a faith alive for a period but not indefinitely; to account for the perpetuity of beliefs one must acknowledge that a faith is shared with others. Further, to feel inspired by religious conviction implies a desire to spread those convictions. Somewhat related to this point, Durkheim makes reference to the emergence of international gods, which are themselves the fruits of tribal mixing, territorial fluidity and the movement of people (428), which today we call global culture. Durkheim anticipates the waning of national borders and the emergence of global sociality that increasingly touches on universal ideals (428-9).

The collective and communicative nature of religion constitutes its enduring, eternal form, even given changes to its substantive features (429). Moral renewal in which shared sentiments are reaffirmed and recreated can only be accomplished with regular assembly (429). The contemporary social theorist may need to be imaginative, supposes Durkheim, for during periods of moral malaise or mediocrity, when the old gods are dying off and new gods have yet to be born, it may be difficult to conceive of such events, especially on a grand collective scale. Durkheim's sociological convictions here lead him to speak in the language of moral prophet, assuring the reader that "new ideals will again spring forth and new formulas emerge to guide humanity for a time" (429). His brief reference to the fleeting but enthusiastic French Revolutionary period provides a secular example of what such a day might look like.

Finally, Durkheim understands himself to have lifted the veil of the "mythological imagination," and perhaps modern rationalist conceit, to reveal the deep affinity between religious and scientific thought. There exists persistent opposition between science and religion, in which the former amounts to the negation of the latter (432). Religion is tied to action and living in a way that science is not, thus Durkheim supposes the conflict to be limited. Even while religion lacks the self-understanding of science, Durkheim contends that religion, rather than fading away, will likely continue to change (432). 
Concerning conceptual thought, Durkheim attends to the shared collective origins of scientific and religious ideas with their characteristics of impersonality and stability, to offer a nascent sociology of knowledge. Durkheim challenges any account of knowledge that imagines sense appearance to be a source of unmediated truth, not least since the key components of logic are not to be found in unmediated observations of the natural world (438). Logic itself is socio-historically emergent and Durkheim credits the Greek Platonist tradition as a key source from which logical life became self-aware (438). Central to Durkheim's theory of religion and human understanding is that beyond the empirical world there exists a "whole system of representations that possess marvelous properties" (438). Both religious and scientific thought fundamentally share dependence on systems of concepts and categories pertinent to all (435). As collective representations, concepts constitute the real basis on which societies are able to think about and reflect upon themselves (436). Collective representations found in religion and science pertain to generalities and to think conceptually is to understand what is most profoundly real (437). The authority of the concept comes from society; thus to be considered "true" any single concept or distinction must align with society. Faith in science is not so different from religious faith because the values of both forms of knowing are found in the social world. Anticipating contemporary sociology, Durkheim explains that the valorisation of science depends on shared ideas about what it is and does for the collective (439).

In the final pages of The Forms, Durkheim expands upon the fundamental categories of thought (e.g. space and time) that provide a framework for all other concepts and classifications. The most important of these categories is that of "totality" (442). Durkheim also draws attention to the conscience collective representing for him "the highest form of psychic life" (445). He again makes reference to an emergent internationalism that continues to push the boundaries of people's understanding of existence (446). Ambitiously, Durkheim claims to have resolved the antimony between science, religion and morality, inasmuch as he has developed an account of how they emerged from the same basis, namely the elementary forms of religious life (446). Durkheim credits Kant for having understood elements of this even if failing to understand the basis of the dual constitution of humans and the dialectical relationship between individual and society that generates the condition of possibility of thought through the gathering of individuals (446-447). Echoing a theme that permeates all of his writings, Durkheim reminds the reader that society is itself a part of nature and its complex forces from which a more elevated kind of life develops, transforming individ- 
ual components through societal combination (447). He reminds us that understanding humanity and its diversity, by examining the nature of the social world that simultaneously transcends and permeates individuals, opens up a powerful explanatory approach within the human sciences. The Forms serves as both argument for, and example of, this.

\section{Theoretical Consequences: Analytical and Critical}

\section{The Disarticulation of the Sacred from Religion}

Durkheim, in a novel way conceptually and analytically disarticulated the sacred from religion providing an alternative to the typical view that "traditional" societies are religious and modern ones "secular" (cf. Berger 2001). In The Forms, the sacred is considered as actual social practice in terms of an operational definition: it is that which is "set apart and forbidden" and something that evokes powerful emotions of awe, respect and horror. This makes it possible to methodologically extend the analysis of the sacred to domains outside of religion, conventionally understood (Turner 2006b). In contrast, religion proper, for Durkheim, refers to the institutionalization of sacralisation pertaining to groups' structuring beliefs (collective representations) and rites (practices; actions) that, combined, form the cult of the moral community.

The disarticulation of the "sacred" from "religion" had a significant impact on Durkheim's broader sociological themes concerning the rise of "moral individualism" and the "cult of the individual" in modern, industrial societies characterized by a complex and highly differentiated division of labour (cf. Fields 1995: xlix-li). Moral individualism has emerged as an explicitly sacred idea and ideal of global sociality (e.g. international human rights; "crimes against humanity"); it is sacred in positive terms (i.e., sacrosanct, [Datta 2010: 179-180]) and is hence a beneficial and potentially integrative collective representation and social fact (Datta 2013). Durkheim also illustrates this kind of disarticulation when he states that "great though the freedom we allow one another may be, it would be tantamount to sacrilege for a man wholly to deny progress or to reject the human ideal to which modern societies are attached" (EFRL: 215). His concept of the sacrosanct status of the human person (the "cult of the individual") and scapegoating of vulnerable persons and groups in moments of social crisis (EFRL: 404), of which anti-Semitism was a prime instance (Durkheim 2008 [orig. 1899]), also points to modern manifestations of the sacred distinct from a traditional institutional basis in "religion." Since the rights, capacities and civic engagement of 
the (modern) individual depend on a complex and egalitarian form of social organization, the "individual human person and collectivity are equally sacred" (Milbrandt and Pearce 2011: 242). Durkheim's practicalpolitical and educational sociology concerned the constitution, development and enhancement of specific social institutions to protect, develop and sustain respect for the sacrosanct value of moral individualism as a sacred ideal that lacked quasi-religious institutional supports.

\section{Modalities of Social Being}

In providing a model of the elemental constitution of society and social life, Durkheim presents us with three modal states of social existence. The first is that of dispersion, characteristic of profane, predominantly pragmatic economic life, in a division of labour necessary to subsistence in which everyone is assigned their task and place. The second is that of ecstatic collective effervescence. The third is the crystallized institutional mode as one finds with an enduring religion, dependent upon the cultic combination of beliefs and practices. This seems too limited a schema for analysing the various qualities given to social life. Even viewing them on a continuum inadequately resolves this. For example, there are moments on the job working with others, possessing moments of joy, effervescence, enthusiasm and creativity. Or, as has been described by noted Christian church historian, Juroslav Pelikan (1973-1990), once effervescent, deeply meaningful religious ceremonies can become dull and routine, just something done habitually on Sundays; likewise, beliefs may become dry, dusty, uninspiring dogmas. Or, one could point to ostensibly effervescent occasions at a party or nightclub where one certainly does not feel like "one of the crowd" and one's sense of radical difference from the revelers can lead to loneliness or even despair.

\section{Collective Effervescence: Phantasmic Origin of the Just Republic?}

There are more than methodological problems with Durkheim's imaginative use of ethnographic data from Australia. Given his concern to reconstitute attachment to the ideals of the French Third Republic, The Forms appears to function as an answer to the problems of civic sclerosis and malaise. In this light, Durkheim's conception of creative collective effervescence as witnessed in the French Revolution is akin to a phantasmic Edenic myth of the founding of the just society, one prior to the law (cf. Zizek 1999: 251-252), a state to which socialised peoples cannot return, and this on Durkheim's grounds. After all, we live in a world of social facts and cannot by an act of will erase that reality. Ironically, believing so was precisely the error, in Durkheim's view, of revolution- 
aries (cf. Durkheim 1961: 258; Pearce 2001: 45) and, we might add, of George W. Bush in believing that toppling the tyrant Saddam Hussein (a coercive social fact) would lead to the flourishing of liberal modern Iraq. Rather, it is necessary to consider the complex conditions of existence necessary to produce freedom and democracy in any society.

\section{Questions of Exclusion and Domination}

There are also significant problems with how Durkheim glosses over the extent to which the sacred depends on domination and exclusion; only initiated men in his empirical cases can be full participants in religious, and by implication, societal life pertaining to the well-being of the tribe. Sacralisation itself and the protection of holy places by rigorously imposed interdictions, make holy places exclusive places, restricted to powerful individuals even while those places are pertinent to all members. Contemporary debates about the ordination of women in Christianity highlight such dynamics. Moreover, the hegemonic status of tribal high gods and the political economy of sacralised collective representations generates "symbolic violence" in which dominant institutions and groups are able to impose an official point of view on social affairs thus delegitimizing, marginalizing, or demonizing others (Bourdieu 1989). The formation of the Christian canon spurred by church leaders mobilizing support for denouncing Marcion, whose theology was deemed heretical, illustrates the point.

Curiously, while he mentions the scapegoating of women in his discussion of piacular rites, and describes exercises of what could be called domination and exclusion, analyses of these phenomena are noticeably underdeveloped. Durkheim addresses scapegoating in "Anti-Semitism and Social Crisis" (2008) but he fails to theorise sacral violence in The Forms (cf. Arppe 2009). Indeed, this oversight contrasts sharply with Girard (1972) for whom the sacred emerges precisely from an act of collective violence on a marginalised person, a victim whose allies are incapable of retaliation. Pertinent in this regard is the extent to which subjugated groups supply ready pools of sacrificial victims feeding, with their blood, the gods of the victors (Pearce 2011).

Durkheim stresses that people feel "good" and empowered by acting "altruistically," ostensibly in the interest of the well-being of "the whole" as understood by a dominant group. Moral force is typically experienced as a sentiment, a feeling and internal force; it may entail a kind of inner buoyancy in which one feels uplifted and becomes stronger, or when one feels the pressure of duties and obligations weighing on one's conscience. The generally positive view of sociality that Durkheim's sociol- 
ogy invites need not imply that simply being together or acting in concert is ipso facto humane and just. Rituals and ceremonies shoring up support for fascist and authoritarian regimes constitute an obvious case in point. Durkheim could be accused of romanticizing the group in The Forms by leaving underexplored how the authority of clan leaders emerges, for example (see Pearce, this volume). Although Durkheim neglects this, it is important to acknowledge that this power and enthusiasm can be put to vastly different and possibly very brutal, fascistic ends (cf. Bataille 1994). Impeded too by Durkheim's focus on a single, elemental case, is adequate attention to antagonistic and competing sacreds within or between tribes. A fair criticism to make of The Forms is that it fails to adequately theorize conflicts and harms arising from the imposition of dominant moral regimes on subordinated individuals, groups and institutions, justified in the name of ensuring the security of the dominant.

\section{Inequality and Privatization: Their Dehumanizing Effects}

As much of The Forms brings into view, the experience of being and acting in concert is the source of love, justice, enjoyment and ultimately freedom. For Durkheim, it is how people are constituted as being able to rise above egoistic interests and appetites closer to humans' animal nature and instead be other-focused, be "good," and embody in practice the goodness of loving, sacrifice, and duty to something beyond oneself. This capacity emerges from actual social practices of assembled groups not least through the empirical apprehension of those practices/rites affecting every participants' or witnesses' conscience; that is how an internal force like one's conscience can be based in the real. Yet, Durkheim was too optimistic about social organisation, neglecting what his own work says about power inequalities and exclusion as inherent to the elemental forms of social life as he describes them.

Still, it is important to read the The Forms within the context of Durkheim's broader writings on modern societies, especially concerning the need to substantially renovate democratic, egalitarian governance. He explained how political and economic organizational forms produce uneven hardships on people, disproportionately benefiting minority dominant groups that reap socially produced rewards unjustly. This was behind his innovative conception of the "forced" and (thus) unjust contract, formulated in the context of "abnormal forms of the division of social labor" (Durkheim 1984[1933]: 310-322). Understood in a modern way, inequality, social exclusion, and inherited privilege thwart genuine, spontaneous solidarity, giving rise to a "forced solidarity" (Pearce 2001: 129). Central here is Durkheim's valorization of humanity as a whole 
and cognizance of the difference and diversity necessary for organic solidarity that itself requires considerations of social justice pertaining to all persons no matter how "different" or even "deviant." Moreover, Durkheim does not simply argue the liberal point about "tolerance" and the need for (negative) rights to protect individuals' liberties: difference is to be facilitated, and groups and the state are obliged to help vulnerable persons and groups in realizing their potential insofar as it benefits and deepens organic solidarity. So, taking Durkheim's broader sociological approach into account, while societal organization can produce unjust hardships on people, it should equally be stressed that society is not inherently a source of corruption. Rather, it is the prime site in which we are made ourselves, and thus, we might say that a society can itself be made more human and be organized from bottom to top to enhance human fulfillment; injustice limits this, but so does privatization.

Durkheim's sociology thus implies that an excessively privatized society, settlement, or institution is also a place that deprives persons of their full humanity, robbing them of possibilities to develop themselves more fully as social persons, in concert, with others (Datta 2012: 532-533). We can think here of such things as excessive car culture or declining government support for public transit (Datta 2013), types of neighborhood design in which there are no safe sidewalks, bylaws prohibiting forms of community engagement in public spaces (Milbrandt 2013), or even forms of parenting advice that discourage children from taking social risks. "To be cut off from (a) communal source of life is to be deprived of resources for individual happiness" (Cladis 2008: 98). Accordingly, one could argue that privatized forms of existence that are built and designed under the auspices of a weak (i.e. egoistic) and not "moral" conception of individualism create the conditions for a uniquely modern kind of moral suffering (cf. Cladis 2008).

\section{A Discursive Monument and Symbolic Feast}

In The Order of Things, Foucault describes in detail the discursive system of possibility of the human sciences, sociology, psychology and literary analysis in particular (1994). He thus provides means for understanding the conditions of possibility of the impact of The Forms and at the same time, a reminder of the circumstance that we still inhabit the same discursive world of Durkheim - sociologists remain contemporaries of the text, and wittingly and not, are frequently intertextually positioned by it. Foucault distinguishes sociology from the other human sciences by noting its attention to how working, producing, and consuming persons 
generate for themselves "a representation of the society in which this activity occurs, of the groups and individuals among which it is divided, of the imperatives, sanctions, rites, festivities and beliefs by which it is upheld or regulated" (Foucault 1994: 355). Foucault's description is certainly befitting of The Forms. But, while Foucault heralds Freud's Totem and Taboo for its contribution to a critical dimension in the human sciences (Foucault 1994: 379), we find The Elementary Forms of Religious Life to be at least as commendable given its scope.

But, how can sociologists account for the circumstance of divergent and conflicting interpretations, appropriations (Foucault 1972: 129, 136), and developments of The Forms (cf. Ramp 2010)? How could work drawing on The Forms inspire the surrealist and phenomenological interpretation offered by Georges Bataille (1989), Talcott Parsons' functionalism (1957), Levi-Strauss' structuralism (1969) and also provide a central resource for the humanist rationalist critical theory of Jürgen Habermas (1987)? These theoretical positions are not exactly compatible! Does this imply that Durkheim's work is itself incoherent and riddled with contradictions (cf. Stedman Jones 2001)? We suggest it does not, but rather points to Durkheim's ambition to push his sociological programme as far as possible, the result being it touched on the entire terrain of the human sciences. In many respects, The Forms writes the totemic emblem of "sociology" on the key concerns and frontiers of the human sciences. Thus we concur with Pearce that Durkheim can be justly counted among Marx, Nietzsche and Freud as a "founder of discursivity" (2001: 9; Foucault 2003: 387).

To consider discursivity is to consider the effects generated by reading and rereading especially concerning the conception of the "object" under investigation and the criteria used to assess knowledge claims (Foucault 1972). Present intellectual times display a great deal of suspicion towards classic texts, particularly those written by the hands of frequently caricatured "dead, white, European males." Prone to challenging "canons" as part of a commendably critical scholarly practice, sociology is also sometimes guilty of deifying "the new" with a fetishistic (perhaps amnesiac) modernism, forgetting "its already hard-won insights" (How 2007, 19; cf. Fields 1994: xii-xxvi; Baehr and O'Brien 1994). Unsurprisingly, engagements with an ambitious work like The Forms have been both positive and negative in tone (cf. Tiryakian 2012; Durkheim 1975: 205-303; Fournier 2013: 628-638; Ramp 2010). But, "there remains the problem of the appropriate stance to take towards 'flawed' work" (Pearce 2001: 2), especially when compounded by entrenched misunderstandings of texts. 
The unfortunately enduring and hegemonic impact of Parsonian functionalist impositions on Durkheim's work, for example, producing serious distortions of Durkheim's sociology, have lead generations of sociology students to dismiss him as a guilty conservative unworthy of serious engagement (Ramp 2008) and unable to account for social change (Stedman Jones 2001: 5-10). Yet, we contend that many of those same students (and their professors!) would very likely consider the power and integrative dimensions of shared symbols for various collectivities (family, city, sport team, social movement, nation, etc.) to be a sociological fact. Along similar lines, while most sociologists accept the utility of Goffman's model of "interaction rituals" as helpful for studying everyday/night life, its Durkheimian underpinnings (drawn significantly from The Forms) are commonly left unacknowledged (cf. Collins 2004; Burns 1991: 26). Gouldner's caution is pertinent: “A science ignorant of its founders does not know how far it has travelled nor in what direction" (1962: 8).

Even justified criticisms need not relegate works to the dustbin. As Pearce notes, "the specification of the inadequate political and epistemological assumptions within a text does not simply discredit it; it still may be an advance in its specific field, and it may be possible to reformulate it so that it is more coherent and productive" (Pearce 2001: 2). Critical and creative engagement requires an ability "to recognize and unravel the different discourses and chains of meaning that lie embedded in any piece of theoretical writing and learn to put theory to good use, rather than simply accepting or rejecting them" (Pearce 2001: xxi). Thus, in addition to its status as discursive monument able to help contemporary sociologists reflexively locate themselves in the epistemic space of the human sciences, The Forms can also be taken up as a symbolic feast. To read the papers in this collection is to confront the circumstance of a plurality of creative and critical engagements with, and appropriations of, a book pertinent to a wide range of sociological sensibilities.

\section{Synopses of Articles}

This collection represents, we believe, a substantial contribution to contemporary Durkheimian scholarship, sociology and social theory broadly speaking. Amid their diversity, these articles well reflect the theoretic robustness of The Forms with their inquiries into a wide range of contemporary social phenomena, including the nature of theorizing itself. Through critical and creative interventions, innovative applications, and the initiation of new lines of inquiry, they re-energise engagements with 
an already animated text, exemplifying the crafts of social analysis and theorizing. Thus, far from The Forms being considered a now surpassed artifact in the "Museum of Classical Theory," or footnote in the history of ideas, throughout this collection Durkheim's multilayered text serves as a significant resource and powerful sociological stimulus. Just as active engagements with The Forms yield new insights into the elementary forms of the sacred and profane shaping collective life today, Durkheim's concepts, categories, questions and models are here productively deployed to consider phenomena unanticipated by Durkheim's own concerns. We suggest that what is being honoured and renewed in recognising the totemic function of The Forms by sociologists (Watts Miller 2012: xi) is the importance of committed, theoretically reflexive sociological practice aiming to explain both shared vexations and ongoing wonder about the sui generis nature of the social. Although they overlap in significant ways, we have divided our synopsis of the articles below into two general categories: those which are primarily concerned with the theoretical implications of The Forms, including its production, reception, and political dimensions, and those that more explicitly draw upon The Forms to analyze specific and contemporary socio-cultural formations and events.

\section{Group I: Reading and Theorizing The Forms}

The first set of papers exemplifies the art and practice of rigorous and committed theoretical research characterized by dialogical readings of The Forms, its place in Durkheim's sociology, and beyond. They offer original, at times quite provocative, interpretations of his sociology of religion. In addition to the broader Durkheimian tradition from which they draw, these interventions are strongly marked by authors' engagements with a range of theoretical resources from Gramsci and Foucault, to Hegel and Lacan. In different ways, they serve as reminders that not everything has been said about Durkheim's work and that puzzles remain, a point noted by Marcel Fournier at the outset of his paper. And further, their different readings, emphases, and lines of inquiry bring into being the inescapably oriented work of theorizing.

In "The Elementary Forms as a Collective Work: Henri Hubert and Marcel Mauss' contributions to Emile Durkheim's Later Sociology of Religion," Marcel Fournier performs what could be called a religious excavation of The Forms. He considers how Durkheim's relation to Judaism may have shaped his understanding of the centrality of religious practices, emphasizing the importance of both ritual and excitement in Durkheim's conceptions of religion and society. His rendering of the in- 
tellectual milieu in which the book was written and critically received displaces the common image of this text as the crowning culmination of Durkheim's theoretical project. Fournier foregrounds the neglected work of the L'Anneé sociologique équipe, especially early writings by Hubert and Mauss, in the germination of some of Durkheim's central ideas. And crucially, he re-opens a question central to any reading of Les Formes: in what sense is religion a distinctive social phenomenon? Fournier's answer is that it involves the ritualistic and representational methods by which collectivities confront the haunting problem of their own disappearance. The elemental problem of group perpetuity is dramatized and made particular by the death of the member. Contributions by Natalie Polzer and Alexander Riley (below) attend to this issue explicitly.

Lionel Obadia reflexively considers and critically interrogates the marginalised place that Durkheim's sociology of religion currently occupies within French sociology. The central concern of the paper is announced in its title: "Is Durkheim's "Sociologism" Outdated? Debating "Individualism" in Contemporary French Sociology of Religion." Obadia argues a definitive "No." He argues that contemporary French repudiations of Durkheimian theory are steeped in profound misunderstandings of Durkheim's conceptions of religion and modern individualism, and their applicability to so-called contemporary "individualized" spiritualities. Obadia identifies and reviews recurring deployments of "individualism" within contemporary French sociology of religion, emphasizing their partial readings of Durkheim. Individualism, Obadia argues, is a complex reality and symbol of modernity to which religious actors (among others) refer. Obadia thus emphasises Durkheim's sociological conceptions of the individual, the sacralisation of the human person, and image of society as a "machine-producing Gods", highlighting the importance of Durkheim's statement that "man alone does not believe." Misunderstandings of Durkheim's central conceptual apparatus he suggests, are symptomatic of a serious misunderstanding of the nature of contemporary societies. Obadia's intervention concludes by recommending a pragmatically oriented sociology in which forms of religious individualism actually produced by individuals and collective actors are given priority.

Central to Alan Blum's contribution is the basis of people's attachment to group life. In "Durkheim's Ruse: The Concept as Seduction," Blum accentuates the ceremonial nature of the symbolic order, arguing that The Forms is at its heart a story about the relation of thought to religion, with the problem of existential ambiguity playing a central, albeit under-acknowledged role. Analysing what he terms the elementary forms of reflective life, Blum proposes that religion functions as a ruse 
in Durkheim's text, as it does in collective life more generally. It permits the modern, purportedly secular subject to develop a spirited relation to ambiguity against the backdrop of the accident of shared membership and the arbitrary, groundless basis of human being. Drawing from ordinary language philosophy ("meaning is use"), Plato, Hegel, Simmel and Lacan, Blum emphasises the centrality of desire within collective life. Desire propels the creation of "concepts" as media for social bonds and conduits for ways of "doing." Like the accident that is one's family name, conceptual distinctions bind members in powerful and enduring ways. Collectively generated concepts are thus read as "images" or "reflections" that mirror modes of being social. Despite their contingency, beliefs and conventions aim to reaffirm the intelligibility of the social order by treating it "as if" it is sacred and untouchable, hence the "ruse." Emphasizing Durkheim's sacred-profane model, totemism, classification and collective representation, Blum argues that the "enigma of ambiguity" is dramatized in The Forms in ways that reveal its constitutive existential consequences. The central lesson of Durkheim's text, Blum argues, is that what fortifies us is our elemental need and desire to be in society. And while captivated by (and largely captive in) social being, members also improvise within the grips of this inescapable condition. Theoretical work itself, including the relation of reader to text, can be read as a sign of such a relationship.

The political (and potentially violent) implications of The Forms is the central focus of William Ramp's article "The Elementary Forms as Political (A)theology." Ramp addresses how The Forms can help us to understand sovereignty and revolution in a manner pertinent to a resurgent interest in political theology. The "disturbing potential" of Durkheim's conception of religion, Ramp argues, has been eclipsed by an emphasis on solidarity and the renewing effects of collective ritual. Ramp directs attention to the significance of the post-revolutionary context within which Durkheim lived and wrote. Raising important questions about the relation of social theorizing to politics, he suggests that the curious absence of an explicit discussion of monarchical sovereignty in The Forms reflects a political and thereby oriented refusal on Durkheim's part. This discursive tactic, Ramp argues, amounts to a "literary decapitation" to preclude the appropriation of Durkheim's own sociology by apologists for monarchism, and reactionaries. His engagement with The Forms thereby re-opens issues concerning sovereignty and absolutism today when notions of social totality are treated with utmost suspicion. Drawing on a range of Durkheim's other writings on revolution (notably his thesis on Montesquieu), and recent writings by Agamben and Kristeva, Ramp develops a conception of the monar- 
chical sovereign as a collective representation and figure made sacred. The rhetorical effect in Durkheim's work is thus that relative inattention to the ancien régime becomes a "political non-act." The scant attention Durkheim gives to significant events such as the Paris Commune, Ramp suggests, may have been partly motivated by his keen sense of how revolutions transform identities and energize actions in ways that can lead to violent excess, while compromising duty, positive social constraint and collective moral force.

Frank Pearce advances an appreciatively critical reading of $E F R L$ in his paper, "Challenging the Anthropomorphic Master Narrative in the Elementary Forms and Forging a More Materialist Durkheimianism." This intervention paves the way for a fruitful synthesis of Durkheimian and Gramscian social theory, inflected with critical realism. Arguing that The Forms is a deeply flawed text, he maintains that its richness can be recuperated through careful engagement with Durkheim's earlier writings on religion and social organisation to elaborate a more nuanced theory of religion than is found in The Forms. Pearce questions the plausibility of Durkheim's claims about the nature of sui generis entities as found with his conceptualization of society, the collective conscience, religion and institutions, each of which have emergent properties. These properties include consciousness and self-consciousness and even a reflexive consciousness. This model of the specific properties of social institutions, social agents and societies can be very useful but becomes problematic when overly reliant on metaphorical and analogical language. Pearce argues that The Forms, in particular, problematically anthropomorphizes sui generis phenomena like society, the collective conscience, and religion rendering them virtually indistinguishable from each other. He challenges this anthropomorphism and Durkheim's ungrounded optimism, which he argues is based on a belief in the inherently positive quality of religion and hope that societies will produce institutions necessary to their existence. Drawing on critical realism and resources in Durkheim where he avoids anthropomorphism, Pearce develops a nonanthropomorphic Durkheimian conception of society as an emergent sui generis entity. Gramsci's conception of class struggle and hegemony is combined with this to complete Pearce's retheorization, resulting in a much renovated model of society based on the asymmetrical articulation of competing overlapping groups rather than on a homogenous collective conscience. 


\section{Group II: Creative Deployments and Contemporary Analyses}

Contemporary cultural analysis and case-study research loom large in this collection, demonstrating the operational possibilities of engaging with The Forms. The second group of studies exemplify the benefits of dialogically reading a classic text in light of contemporary circumstances and research strategies. The emotional intensities of collective forms are emphasized in compelling ways throughout this section, and through quite varied phenomena. Major themes from The Forms that figure prominently in these pieces include the heterogeneity of the sacred and profane, the generative possibilities of effervescent gatherings, totemism, the production of the sacred through potent symbolic representations, and the sacred as an essentially energizing social force.

In "The Elementary Forms of Carnival: Collective Effervescence in Germany's Rhineland", Yvonne Niekrenz explores the structure and meaning of contemporary carnivals. She emphasises their spatial, temporal and embodied structuring frames, and the pleasurable forms of social frenzy that such events engender for participants. Her study is a compelling contemporary illustration of the process by which the sacred comes to be disarticulated from formal religious institutions. Drawn from an ethnographic study of an annual Rhenish street carnival, the "extraordinary" lifeworld of carnival is conveyed by the inclusion of participant comments, field observations and local textual materials pertaining to various street events that punctuate the paper. Revealing its fading, historical Christian (Roman Catholic) roots, the continued celebration of this traditional festival is, indeed, puzzling. To account for its perpetuity, Niekrenz argues that such collective and liminal events are magnified occasions in which actors confront and enjoy the place of ambivalence in contemporary social life. Her reading of Durkheim emphasizes the potency of collective assembly and effervescence, highlighting the efficacy of social rituals, emotional intensities generated through embodied social congregation, the importance of social renewal and the generation of solidarity through "corroboree." Her analysis draws fruitfully from Maffesoli's conceptions of post-modern tribalism, proxemics, and Dionysian social energies. The ethnographic detail brings to the fore a variety of contradictory social experiences that Niekrenz argues are part of the "extraordinary realities" and ambivalences that carnival time brings into being: mortality and finitude, the intermixing of sacred and secular, movement and play, sensuality and intoxication, and the opposition between order/disorder. Stressing the play of social forms, and accentuating the emotional and embodied dimensions of collective experiences in shared spaces and consecrated times, Niekrenz's study draws 
productively on The Forms to analyze a contemporary event, in ways that emphasize and illustrate the sacred dimensions of secular culture in a globalizing era.

In "The Market Totem: Mana, Money, and Morality in Late Modernity," James Cosgrave draws upon The Forms to put forth a new analytic framework for theorizing global financial markets within the current global capitalist economy. The key to this framework is the conceptualization of "the market" as a totem. Drawing on familiar visualizations, such as the movement of the stock ticker and the economic chart as domains of collective representation, Cosgrave develops a picture of the dynamic and volatile character of markets as late modern "totemic entities" which signify sacralised aspirations, beliefs and values of contemporary capitalist societies. "The market," he emphasizes, is an essentially collective phenomenon irreducible to individual actors or transactions. By drawing on and developing Durkheim's early approach to economic anomie, alongside The Rules of Sociological Method, Cosgrave analyses markets as "social facts" that are external to and coercive upon people, and which generate particular ways of "thinking, acting and feeling" (Durkheim 1982: 52). Cosgrave considers how the social bases of markets generate powerful emotional investments, organized around hopes that financial investments will rise to confer wealth (the capitalist forms of mana) and fears that they will fall. While Durkheim may have denounced the modern "market society" as socially dangerous and immoral in his earlier writings, Cosgrave's analysis paves the way for a potentially fruitful Durkheimian-guided framework to theorize the emergent and totemic features of contemporary markets and marketrelated phenomena, including speculation and confidence. Cosgrave's contribution is especially pertinent in the context of what can be identified as a period of anomie within the global capitalist economic system.

The articles by Natalie Polzer and Alexander Riley are Durkheimian analyses of the social meanings of commemorative rituals pertaining to traumatic world-historic events, namely the Jewish Holocaust (Polzer) and the 9/11 terrorist attacks against the United States (Riley). Polzer's article, "Durkheim's Sign Made Flesh: The 'Authentic Symbol' in Contemporary Holocaust Pilgrimage" is a theoretical intervention and also a qualitative and comparative study of the ritual uses of Holocaust relics in three distinctive and contemporary transnational pilgrimage contexts. Developing an innovative synthesis between Durkheim's notion of "sacred symbol" and Benjamin's conception of "authenticity," Polzer advances the concept of the "authentic symbol" to account for the transformed nature of religious symbols in transnational contexts. Descriptions of the bodily remains and clothing of the doomed are woven 
into her narrative in ways that illustrate how "authentic symbols" are put to work and engaged by participants in socially powerful ways. Highly ritualized sequences and structured experiences embodying elements of Durkheim's negative and positive cult are richly detailed throughout the analysis. The demand for "authentic" artifacts, Polzer emphasizes, is not unique to Holocaust pilgrimage nor even religious experience; rather it is feature of Western modernity dating as far back as late nineteenth century forms of tourism. It can also be seen in the contemporary cultural form of "Dark Tourism." While Polzer draws productively upon Durkheimian categories throughout the paper, particularly in relation to the structure of ritual practices and the sacred as a fundamentally energizing social force, she argues that the contemporary insistence on "authenticity" demands a modification of his conception of the relation between the symbolic and empirical/material. As well as offering a powerful contemporary case study, Polzer's work points toward a critical Durkheimian phenomenology. Through her cases, Polzer demonstrates how collective representations and rituals are conditions in and through which persons come to understand a set of traumatic events at a deeply subjective level.

Significantly, Polzer's work provides a neo-Durkheimian reply to Agamben's charge, one that can be traced back to Levi-Strauss (1969; Hénaff 1998) that the Durkheimian conception of the sacred reduces to psychologism (Agamben 1998: 77-78). What Agamben misses is the sociological import of attending to the affective and deep phenomenological consequences of sacralisation and the systems of exclusion that both constitute and sustain them. Emotions point to how what is external to an individual's consciousness comes to be manifest in the heart of subjectivity itself, frequently unwittingly reproducing sacred differences. Marked shifts in affective states are thus a methodological indicator of the constraint and power of the social as it resides in, and has consequences for, subjective formations.

Alexander Riley's contribution, "Flags, Totem Bodies, and the Meanings of 9/11: A Durkheimian Tour of a September $11^{\text {th }}$ Ceremony at the Flight 93 Chapel" is a rich cultural sociological analysis of an ideal-typical commemorative religious ceremony at the "Thunder on the Mountain Chapel" in Shanksville, Pennsylvania. This is a chapel devoted to the memorialization of those who lost their lives on Flight 93, the third plane to have crashed on that globally fateful day. Using ethnographic methods, he attends to the neglected effects of " $9 / 11$ " and its ongoing story within the longer narrative of the sacrificial cult in American civil religion. Riley makes the convincing case that understanding the structure of totemic religion provides heuristic means for contemporary cultural analysis of the sacred in US life. Riley's description and 
analyses of services at the Chapel compellingly reveal how "clan" and "totem" are constituted and replenished in the face of the sacrificial death and blood of the "heroic" member, one who sacrifices her/himself to protect the community. The US flag serves as representation of the dead national hero and hence partakes of and condenses what is held sacred in American civil religion.

In complementary and contrasting ways, Riley and Polzer emphasize the constitution and effects of symbolic potency in contemporary commemorative rituals. Both highlight the social meanings generated for participants through commemorative rituals, emphasizing the powerful creation of bonds between living and dead, that is, between the mortal group member - who may be asked to sacrifice for the group in the future - and the "eternal life" of the collective in the face of traumatic loss (death). Nationalism and the readiness to sacrifice for the collectivity, be it the states of Israel (Polzer) or the USA (Riley) in the form of possible future military service, are important themes raised in both cases. They underscore the need for further investigation of the relations between religiosity, nation, war and militarism in contemporary society, while troubling the politics of sacrifice and sacralisation.

Finally, Mervyn Horgan's article "Durkheim, Development and the Devil: A Cultural Sociology of Zoning Conflict" is a case study of a recent conflict over a rezoning proposal for agricultural land in rural Nova Scotia. Like Riley, Horgan builds on the neo-Durkheimian cultural sociological tradition pioneered by Jeffrey C. Alexander. Guided by this approach and drawing on a detailed study of a land proposal that was ultimately defeated, his study affirms Durkheimian-derived insights into the centrality of the sacred-profane binary in organizing the civic sphere. By showing how symbolic power is also a moral power, Horgan analyses the creation of moral community through meaningful invocations of the sacred, in this case, the sanctity of farmland. Drawing on ethnographic materials in ways that bring Durkheim's conceptual apparatus to new life, Horgan's study includes a rich examination of the dynamic relationship between beliefs and rites within the political life of a farm community. His study of the symbolic and material battle over the value and use of low-density rural land provides means for challenging the implicit urban imperialism underlying much of the contemporary social sciences literature on municipal politics. Horgan's study invites further comparative examination of how notions of the "local" can become sanctified and energizing for community members in the face of socially dangerous, and apparently "outside" influences (such as land speculation). 


\section{Discussion: O Canada?}

Before concluding, we wish to draw attention to the displacement of "Canada" in the genealogy of Durkheim's book, and hence too, in the formation of modern sociology and social theory. Certainly, there is no denying the significance of the Australian case for Durkheim as has been exceptionally well discussed by Watts Miller (2012). But The Forms contains numerous footnotes detailing Durkheim's reference to aboriginal peoples in Canada, drawing on Franz Boas' research in particular. For instance, Durkheim notes the use of special ceremonial masks on the North West Coast $(114, \mathrm{n} 76)$, Haida and Iroquois beliefs about the descent of man [sic] from animals (135), a Kwakwaka'wakw (Kwaikiutl) legend from British Columbia $(136$, n34), the belief in sacred parts of the body "among the Hurons, the Iroquois and the Algonquins" (158, n3) and the Algonquin "manitou" is cited as an example of the notion of the totemic principle (EFRL: 196), something made familiar to Canadians through the winter holiday song, "Huron Carol."

Most significantly, it is little known beyond specialists in the history and development of Durkheimian social science, that an essay by Durkheim's nephew and closest collaborator, Marcel Mauss, supplied Durkheim with the idea of "collective effervescence" in his work with Henri Beuchat, Seasonal Variations of the Eskimo: A Study in Social Morphology (Mauss 1979 [1906]; Fournier 2013: 506-507; 612; see also Fournier, this volume). We see Mauss discussing "Baffin Island and the northern shores of Hudson Bay," "Labrador," and the "Saint Lawrence area of northern Canada" (Mauss 1979: 24).

According to extensive ethnographic reports of Arctic peoples, individual families disperse and engage in hunter-gatherer activity in summertime. In the winter months, families return to a shared, collective "settlement," "a group of assembled families who are united by special ties and who occupy a habitat [... consisting of] a concentration of houses, a collection of tent sites, plus hunting-grounds on land and sea" (Mauss 1979: 27). In wintertime, assembled families participate together in on-going festivities. As Mauss writes, "One can thus describe winter life as one long celebration," involving "non-stop religious life" (58). In a manner presaging The Forms, Mauss notes that,

Winter is a season when Eskimo society is highly concentrated and in a state of continual excitement and hyperactivity. Because individuals are brought into close contact with one another, their social interactions become more frequent, more continuous and more coherent; ideas are exchanged; feelings are mutually revived and reinforced. By its existence and constant activity, the group becomes more aware of itself and assumes a more prominent place in the consciousness of individuals (Mauss 1979: 76) 
In short, the oscillation between two distinct phases of social life (summer and winter) constitute the basis on which social morphology, the organisation of space, community, identity and knowledge are combined into a total social system. And yet, Mauss' study of Arctic peoples receives but one mention in The Forms in Durkheim's concluding remarks on the cycles of social life (354; Fournier 2013: 619).

Henri Beuchat, a young member of the Durkheim research team and student of Mauss, was to be the Canadian specialist. He was sent to do fieldwork in the Canadian Arctic on the recommendation of "Marius Barbeau, one of the first members of Edward Sapir's team in Ottawa to set up the Canadian Arctic Expedition of 1913-1916" (Mauzé 2004: 64). "Unfortunately, in January 1914 the boat on which Beuchat was traveling, the Karluk, sank. The young French ethnographer who could have become an expert on Eskimo culture died of cold and hunger on Wrangell Island off the coast of Alaska. [...] His tragic death may have put an end to the development of French research in North America" (Mauzé 2004: 64; cf. Fox 1979: 14-15). While Beuchat faced a tragic end, we hope that drawing attention here to the neglected impact of Canadian data on Durkheimian studies will spur, along the lines recommended by Riley (2010), new reflexive, critical, historical work on the "imagined Canada" in Durkheimian sociology and anthropology.

\section{Conclusion: Being Charmed; Being Otherwise}

Our own reasons for continually engaging with Durkheim's magnum opus, The Elementary Forms of Religious Life, largely stem from his conception of the life and dynamism of the social, its complexity, and ambivalent powers. As evinced by his oeuvre, Durkheim had a remarkable capacity for conceptualising the bonds constituting enduring societies, and a commitment to explaining imminent threats to what is most humane and promising in contemporary societies. This distinctive Durkheimian sociological approach is accompanied by his sense that combining theoretical work, empirical research and practical-political concerns is constitutive of the best of sociology as a social science pertinent to all. The Forms is exemplary in these respects and the array of questions, concepts, categories and models developed and deployed in the book touch on all of the major contours of the epistemic space of the human sciences. This is why it is a "monumental" work containing rich material for the kind of symbolic feast of contemporary engagements evinced by the contributions in this volume. 
The tendency of conventional forms of religious piety to wane with capitalist development and complex state formation, alongside the waxing of "spirituality" in which individuals draw on a range of beliefs about the sacred, rites, symbols and trappings to create personalised microsyncretisms, need not imply that Durkheim's focus on the power of social institutions geared toward "higher things" and la vie sérieuse, is no longer sociologically pertinent in complex societies, especially in the global north. As suggested by recent empirical research by Abby Day (2011), contemporary religious persons in the global north are already practical Durkheimians (if unwittingly), attending services and participating in the activities of collective worship and charitable works precisely because they enjoy and draw strength from participating in a moral community, caring for and doing things with others. In Durkheimian terms, they are being social. As demonstrated by the contributions herein, neither does the decline of "official religion" require a narrowed research programme restricted to the conventional concerns of the sociology of religion (cf. Turner 2006b).

Durkheim's work suggests that in moments of collective effervescence humans constitute the actuality of their own immediate, immanent, yet transformative power. This is a human power to constitute radically different social actualities. For him, to discover, experience and conceptually apprehend the social power of being together with others, serves to remind us of a radical otherness in all persons. This is not the "Otherness" of the "Others" depicted by nineteenth century anthropology; neither is this the otherness and peculiarity of how "we" once were, as narrated by historians; nor is it the "otherness" of our psychical structures as explored by psychoanalysis and surrealism. Rather, it points to the "otherness" of what we can be.

It is this existential constitution of the human animal as social via collective representations that receive the transfer of collective sentiment that fundamentally makes it possible for a person to genuinely care about others, to be considerate and experience that which makes the power of justice possible, even when people do not feel so inclined. This is a paramount concern in Durkheim's work, one evinced in his first major work The Division of Labor in Society. Anticipating his later conception of the joys of collective effervescence in The Forms, he stresses that the requirements of moral life, facilitative of life together, are not simply a matter of rules and duties in which we sacrifice our own interests for the betterment of others without getting something powerful and beneficial in return. As he puts it in The Division of Labor in Society, 
At the same time that our energies are freed from their daily obligations, from their regular duties, they feel the need of tearing loose, of playing in new circumstances where rules are neither determined nor imposed, for the pleasure of doing and the joy of being free [...]. It is this need which inspires all gratuitous acts we accomplish, from the refinements of worldly urbanity, the ingenuities of politeness, the losing of sympathy in the midst of the family, the kinds of attentions, the gifts, affectionate words or caresses between friends or relatives, up to the most heroic sacrifices that no duty demands. For it is wrong to believe that these noble inventions, as they are very justly called by Janet, are met with only in extraordinary circumstances. They are invested with the greatest importance; life is full of them; they invest it with charm (Durkheim 1933[1893]: 430-431, emphasis added).

Thus, for Durkheim, doing what is right and good, moral and just, can also feel good because it is consistent with an ontological harmony through which people are constituted as persons in the first place.

This suggests to us that The Forms serves to remind the sociologist that it is the joy and love of being together that makes life livable. As Durkheim poetically states, "The only hearth at which we can warm ourselves morally is the hearth made by the company of our fellow men" (EFRL: 427). Of course, we take Durkheim to mean our fellow person, for it would be inconsistent with his conception of a solidaristic social order to imagine that moral life, and its continuous regeneration, applied to less than half of all social members. Certainly, there are obstacles to universalising love, justice, and solidarity, as Durkheim was so well aware, but these are not insurmountable because such obstacles are also social, sharing in its nature as historically emergent. The Forms is thus, in the end, a sociologically optimistic book reminding us that we have unactualised potentials for being more humanely otherwise, together.

\section{REFERENCES}

Agamben, Giorgio. 1998. Homo Sacer: Sovereign Power and Bare Life. Trans. Daniel Heller-Roazen. Stanford: Stanford University Press.

Agamben, Giorgio. 2009. What is an Apparatus? Stanford: Stanford University Press.

Alexander, J. 2006. The Civil Sphere. Oxford and New York: Oxford University Press.

Allen, N. J., Pickering, W. S. F. and Watts Miller, W., Eds. 1998. On Durkheim 's Elementary Forms of Religious Life. New York: Routledge. 
Arppe, Tiina. 2009. Sacred violence: Girard, Bataille and the vicissitudes of human desire. Distinktion: Scandinavian Journal of Social Theory 10(2):31-58.

Baehr, Peter and O'Brien, Michael. 1994. Founders, classics and the concepts of a canon. Current Sociology 42(1):1-151.

Bataille, Georges. 1994[1933]. The Psychological Structure of Fascism. Pp. 137160 in Visions of Excess. Ed. Allan Stoekl, trans. Allan Stoekl with Carl. R. Lovitt and Donald M. Leslie Jr. Minneapolis: University of Minnesota Press.

Bataille, Georges. 1989. Theory of Religion. Translated by Robert Hurley. New York: Zone Books.

Berger, Peter L. 2001. Reflections on the sociology of religion today. Sociology of Religion 62(4):443-454.

Bourdieu, Pierre. 1989. Social space and symbolic power. Sociological Theory, 7(1):14-25.

Burns, Tom. 1991. Erving Goffman. New York: Routledge.

Cladis, Mark S. 2008. Suffering to Become Human. Pp. 81-100 in W.S.F. Pickering and Massimo Rosati, eds., Suffering and Evil: The Durkheimian Legacy. New York and Oxford: Durkheim Press/ Berghahn Books.

Collins, Randall. 2004. Interaction Ritual Chains. Princeton: Princeton University Press.

Datta, Ronjon Paul. 2008. Politics and existence: Totems, dispositifs and some striking parallels between Durkheim and Foucault. Journal of Classical Sociology 8(2):285-307.

2010. From political emergencies and states of exception to exceptional states and emergent politics: A neo-Durkheimian alternative to Agamben. Pp.169-183 in Durkheim and Violence, International Social Science Journal, UNESCO: Paris and Oxford: Wiley-Blackwell.

. 2012. Recent Anglo-American studies on Durkheim's sociology. L'Année Sociologique 62(2):527-536.

2013. Mundane Cosmopolitanism, Mobility and Social Justice: A Durkheimian Approach. Pp. 76-102 in Suzan Ilcan ed., Mobilities, Knowledge and Social Justice. Montreal \& Kingston: McGill-Queen's University Press.

Day, Abby. 2011. Believing in Belonging: Belief and Social Identity in the Modern World. Oxford: Oxford University Press.

Durkheim, Émile. 1933[1893]. The Division of Labor in Society. Trans. George Simpson: New York: The Free Press.

-1961. Moral Education. New York: The Free Press.

1962. Socialism. Edited by Alvin. W. Gouldner and translated by Charlotte Sattler. New York: Collier Books. 
1973 Individualism and the Intellectuals.Pp. 43-57 in Émile Durkheim on Morality and Society. Ed. Robert N. Bellah, trans. Mark Traugott. Chicago: University of Chicago Press.

1975. Durkheim On Religion: A Selection of Readings with Biographies and Introductory Remarks. Ed. W. S. F. Pickering, trans. Jacqueline Redding and W. S. F. Pickering. Cambridge: James Clark \& Co.

- 1978. Sociology and the Social Sciences. Pp. 71-90 in Emile Durkheim: On Institutional Analysis, ed. and trans. Mark Traugott. Chicago: University of Chicago Press.

-1982. The Rules of Sociological Method and Selected Texts on Sociology and its Method, ed. Steven Lukes, trans. W. D. Halls. New York: The Free Press.

- 1984 [1893]. The Division of Labor in Society, ed. Lewis A. Coser, trans. W. D. Halls. New York: The Free Press.

2008 [1899]. Anti-Semitism and social crisis. Sociological Theory 26(4):321-323.

Fields, Karen E. 1995. Translator's Introduction: Religion as an Eminently Social Thing. The Elementary Forms of Religious Life, by Emile Durkheim, xvii-lxxiii.

Fox, J. J. 1979. Translator's Foreword. Seasonal Variations of the Eskimo: A Study in Social Morphology. (With Henri Beuchat). New York: Routledge: 1-17.

Foucault, Michel. 1972. The Archaeology of Knowledge. New York: Pantheon Books.

.1979. Discipline and Punish: The Birth of the Prison. New York: Vintage Books.

.1994. The Order of Things: An Archaeology of the Human Sciences. New York: Vintage Books.

2003. What is an Author? Pp. 377-391 in The Essential Foucault eds. Paul Rabinow and Nikolas Rose. New York: The New Press.

Fournier, Marcel. 2013. Émile Durkheim: A Biography. Trans. David Macey. Malden, MA: Polity Press.

Gane, Mike. 1983. Durkheim: The Sacred Language. Economy and Society. 12(1):1-47. 1988. On Durkheim's Rules of Sociological Method. New York: Routledge.

Garfinkel, Harold. 2002. Ethnomethodology's Program: Working Out Durkheim's Aphorism. Lanham: Rowman \& Littlefield.

Gouldner, Alvin W. 1962. Introduction. Pp. 7-31 in Socialism by Émile Durkheim. New York: Collier Books. 
Habermas, Jürgen. 1987. The Theory of Communicative Action: Volume Two, Lifeworld and System. Boston: Beacon Press.

Hénaff, Marcel. 1998. Claude Lévi-Strauss and the Making of Structural Anthropology. Minneapolis: University of Minnesota Press.

Hertz, Robert. 1960. Death and the Right Hand. Illinois: The Free Press.

Inglis, David. 2011. A Durkheimian Account of Globalization: the Construction of Global Moral Culture, Durkheimian Studies/Études durkheimiennes. (17)103-120.

Inglis, David and Roland Robertson. 2008. The Elementary Forms of Globality: Durkheim and the Emergence and Nature of Global Life, Journal of Classical Sociology. (8):1:5-25.

Kristeva, Julia. 2002. Revolt, She Said, Translated by Brian O'Keeffe, Los Angeles: Semiotext[e].

Lacroix, Bernard. 1979. The elementary forms of religious life as a reflection on power (objet pouvoir). Critique of Anthropology 4:87-103.

Levi-Strauss, Claude. 1969. The Elementary Structures of Kinship, trans. James Harley Bell, John Richard von Sturmer, and Rodney Neeham. Boston: Beacon Press.

López, José. 2003. Society and Its Metaphors: Language, Social Theory and Social Structure. London and New York: Bloomsbury.

Lukes, S. 1992. Emile Durkheim: His Life and Work. Toronto: Penguin Books.

Mauss, Marcel. 1962. Introduction to the First Edition. Pp. 32-36 in Socialism by Émile Durkheim. Edited by Alvin. W. Gouldner and translated by Charlotte Sattler. New York: Collier Books. New York: Collier Books.

.1979. Seasonal Variations of the Eskimo: A Study in Social Morphology. (With Henri Beuchat). New York: Routledge.

Mauss, Marcel and Hubert, Henri. 2001. A General Theory of Magic. Translated by Robert Brain. New York: Routledge.

Mauzé, Marie. 2004. When the Northwest Coast Haunts French Anthropology: A Discreet but Lasting Presence. Pp. 63-85 in Coming to Shore: Northwest Coast Ethnology, Traditions, and Visions, Marie Mauzé, Michael E. Harkin, and Sergei Kan (eds.). Lincoln: University of Nebraska Press:63-85.

Milbrandt, Tara. 2013. Signs of the City: Space, Place, and the Urban Street Poster. Pp. 49-70 in Captured by the City: Perspectives in Urban Culture Studies, edited by Blagovesta Momchedjikova. Newcastle upon Tyne: Cambridge Scholars Press.

Milbrandt, Tara and Frank Pearce. 2011. Emile Durkheim. Pp. 236-282 in The Wiley-Blackwell to Major Social Theorists: Volume I, Classical Social Theory, edited by George Ritzer and Jeffrey Stepnisky. Chichester: Wiley-Blackwell. 
Morrison, Ken. 1995. Marx, Durkheim, Weber: Formations of Modern Social Thought. London and Thousand Oaks: Sage Publications Inc.

Parsons, Talcott. 1957. The Structure of Social Action. New York: McGraw-Hill

Pearce, Frank. 2001. The Radical Durkheim, 2nd Edition. Toronto: Canadian Scholars' Press Inc.

Pearce, Frank. 2010. Obligatory Sacrifice and Imperial Projects. Pp. 45-66 in William Chambliss ed. State Crime in the Global Age. New York: Willan.

Pelikan, Jaroslav. 1973-1990. The Christian Tradition: A History of the Development of Doctrine, 5 Volumes. Chicago. University of Chicago Press.

Ramp, William. 2008. Durkheim redux. Journal of Classical Sociology 8(2):147157.

2010. Durkheim and After: Religion, Culture, and Politics. Pp. 52-75 in Bryan S. Turner ed., The New Blackwell Companion to the Sociology of Religion. Malden, MA: Blackwell Publishing Ltd.

Riley, Alexander Tristan. 2010. Godless Intellectuals? The Intellectual Pursuit of the Sacred Reinvented. New York: Berghahn Books.

Rosati, Massimo. 2008. Inhabiting no-man's land: Durkheim and modernity. Journal of Classical Sociology 8(2):233-261.

Rawls, Anne Warfield. 2001. Durkheim's treatment of practice: Concrete practice vs. representations as the foundation of reason. Journal of Classical Sociology 1(1):33-68.

2012. Durkheim's theory of modernity: Self-regulating practices as constitutive orders of social and moral facts. Journal of Classical Sociology 12(3-4): 479-512.

Stedman Jones, Susan. 2001. Durkheim Reconsidered. Cambridge: Polity Press. .2010. Durkheim, the Question of Violence and the Paris Commune of 1871. Pp. 63-82 in Durkheim and Violence, International Social Science Journal, ed. S. Romi Mukherjee. UNESCO: Paris and Oxford: WileyBlackwell.

Strawbridge, Sheelagh. 1982. Althusser's theory of ideology and Durkheim's account of religion: An examination of some striking parallels. The Sociological Review 30(10):125-140.

Tiryakian, Edward A. 1995. Collective effervescence, social change and charisma: Durkheim, Weber and 1989. International Sociology. 10(3): 269281.

2012. Early reviews of the elementary forms of religious life. Journal of Classical Sociology 12(3-4):513-252.

Traugott, Mark, ed. 1994. Emile Durkheim on Institutional Analysis. Chicago: University of Chicago Press. 
Turner, Bryan S. 2006a. Classical sociology and cosmopolitanism: A critical defence of the social. The British Journal of Sociology, 57(1) 133-151. .2006b. Religion. Theory, Culture \& Society 23(2-3):437-455.

Watts Miller, William. 2012. A Durkheimian Quest: Solidarity and the Sacred. New York: Berghan Books.

Woodiwiss, Anthony. 2005. Scoping the Social: An Introduction to the Practice of Social Theory. Berkshire: Open University Press.

The listing of author names in this project is alphabetical. Both authors contributed equally to this paper, and the editorship of the issue.

Ronjon Paul Datta is an Assistant Professor in the Department of Sociology, Anthropology and Criminology at the University of Windsor. He specializes is contemporary and classical social theory (metatheory in particular) and has published several works on Durkheim and contemporary social theory, cosmopolitanism, Foucault, Deleuze, zombie capitalism, anti-security, aleatory materialism, and critical realism. Paul is co-founder and co-secretary of the Canadian Network of Durkheimian Studies/Réseau canadien d'études durkheimienne (CNDS/RCED), a Developing Research Cluster of the Canadian Sociological Association. He dedicates his work for this special issue to the memory of his father, Manik Bhupati Bushan Datta (1933-2014), who first taught him the meaning of faith.

Email: rpdatta@uwindsor.ca

Tara Milbrandt is an Associate Professor of Sociology in the Department of Social Sciences at the University of Alberta's liberal arts and sciences Faculty of Augustana. She has published work in the areas of urban culture, public space, mediated suffering, and contemporary visualizing practices. Synthesizing radical Durkheimianism, visual, and interpretive theory, her current research explores changes in the nature and experience of public life, morality and selfhood in our late modern era of incessant photographing and image circulation. Tara is co-founder of the Canadian Network of Durkheimian Studies/Réseau canadien d'études durkheimienne (CNDS/RCED), a Developing Research Cluster of the Canadian Sociological Association.

Email: tara.milbrandt@ualberta.ca 